\title{
EFFECTS OF ANTIMICROBIAL INTERVENTIONS AND BRINING ON MICROBIOLOGICAL QUALITY OF 6 MONTHS' QUICK FROZEN CHICKEN MIXED PORTIONS
}

\author{
MASHISHI, M. D. ${ }^{1}-$ OKORO, V. M. O. ${ }^{1 *}-$ MBAJIORGU, C. A. ${ }^{1}$ \\ ${ }^{I}$ Department of Agriculture and Animal Health, College of Agriculture and Environmental Sciences, \\ University of South Africa, Florida, 1710, South Africa \\ *Corresponding author \\ e-mail: melavicong@gmail.com, phone: +27-78-938-9749 \\ (Received 27 $7^{\text {th }}$ Dec 2018; accepted $14^{\text {th }}$ Feb 2019)
}

\begin{abstract}
This study was to know the effects of abattoir, chlorinated antimicrobial intervention and brining on microbiology of post 6 months' frozen $\left(-10 \pm 2{ }^{\circ} \mathrm{C}\right)$ and thawed mixed chicken portions, as well as determine the optimal brining levels. Broilers (5-6 weeks old, $\mathrm{n}=180,1.12-1.25 \mathrm{~kg}$ carcass weight) processed at 3 different processing plants ( $\mathrm{n}=60$ per abattoir) into chicken portions of breasts, thighs and wings were packaged in $1 \mathrm{~kg}$ bags after applying antimicrobial intervention and brining before quick freezing them. After 6 months quick freezing at $-10^{\circ} \mathrm{C}$ and thawing, standard plate counts (SPC), spore counts and psychrophilic counts (log cfu/g) were evaluated and subjected to ANOVA in a randomized complete block design (RCBD). No coliforms, molds, staphylococci, and yeasts were not detected due to abattoir, antimicrobial and brining interventions. Also no significant SPC, spore count and psychrophilic bacterial count $(\mathrm{P}>0.05)$ effects was recorded due to abattoirs. ASC significantly $(\mathrm{P}<0.05)$ lowered all the counts compared to Aq. $\mathrm{Cl}$ and $\mathrm{ClO}_{2}$. The $0 \%$ brine had highest $(\mathrm{P}<0.05)$ counts $(3.33,3.25$ and $3.63 \log \mathrm{CFU} / \mathrm{g}$ ) for SPC, spores and psychrophilic bacteria respectively, while 30 and $35 \%$ levels had the least $(\mathrm{P}<0.05)$ counts (ranges from $1.06-1.87 \log \mathrm{CFU} / \mathrm{g})$ per sample tested with no significant interaction effects recorded. There is a significant optimal brining levels of 13.27, 35.87 and 34.10 (\%) for SPC, spores and psychrophilic counts based on the quadratic regression model.
\end{abstract}

Keywords: psychrophilic bacteria, quadratic function, aqueous chlorine, standard plate count, freezing

\section{Introduction}

Food preservation using low temperatures is the most commonly used method for storing fresh foods as well as its distribution. Fresh meat is among the most perishable foods and chill temperatures are mostly used to delay the spoilage process by spoilage bacteria after slaughter, processing cuts and portions, transportation to distributors and the final storage at various retail sites (Xia et al., 2009). The basic aim of cooling techniques for fresh meat preservation is to slow or limit the spoilage rate as temperature below the optimal range can inhibit the microbial growth (Cassens, 1994). The methods of temperature regulation for storage are chilling, freezing and superchilling which help to inhibit or completely stop bacterial growth (Zhou et al., 2010). However, the growth of psychrophilic group of bacteria, yeasts and molds is not prevented by all levels of refrigeration (Neumeyer et al., 1997) and both enzymatic and non-enzymatic changes will continue at a much slower rate (Van Berkel et al., 2004). During freezing, about $60 \%$ of the viable microbial population dies but the remaining population gradually increases during longer frozen storage periods (Rahman, 1999b). Modi et al. (2006) and Sudheer et al. (2011) reported an increase in psychrophilic bacterial count in prolonged freezing storage of spiced chicken.

Most psychrophilic bacteria belong to the microbial genera of both gram positive, such as lactic acid bacteria, and gram-negative bacteria such as Pseudomonas spp. and 
Enterobacteriaceae (Holzapfel, 1998). Particular species involved in the spoilage of meat preserved at chill temperature are of Pseudomonas spp. (Ercolini et al., 2007), while the microflora of vacuum packaged frozen-preserved meat is characterized mostly by psychotropic lactic acid bacteria (Nychas et al., 1998). It is assumed that antimicrobial intervention and brining before freezing could significantly reduce such spoilage microbes during long frozen preservation periods, however there is paucity of information on spoilage microbial load of chicken portions thawed after quick frozen at $-10{ }^{\circ} \mathrm{C}$ for 6 months.

The poultry processing plants make use of antimicrobial interventions (chlorine antimicrobials) such as aqueous chlorine, chlorine dioxide and Acidified Sodium Chlorite to abate the effects of spoilage bacteria as the storage period increases (AlonsoHernando et al., 2013). Also, the poultry processing industry had introduced the method of brining for processed chicken with an objective of improving the flavour, taste and tenderness of chicken through different liquid additive solutions (Venter, 2015). Although, there is paucity of scientific report on the effect of high levels of brining on the portion's microbial load and its effects on the chicken, it had been speculated that increased brining levels above $60 \%$ could result in high levels of salts in the products which could affect the consumer's health (Alvarado and McKee, 2007; Ellinger, 1972). However, there is paucity of information on the effects of antimicrobial intervention and brining on the level of standard plate counts (SPC), spore counts and psychrophilic counts $(\log \mathrm{cfu} / \mathrm{g})$ in 6 months frozen chicken portions, as well as the optimum levels of inclusion to attain the lowest microbial count in frozen chicken portions.

Therefore, this study is aimed at determining the relative effects of antimicrobial intervention and brining on spoilage microbial load in long term (6 months) frozen chicken portions; determine the best chlorinated antimicrobial to be used among the commonly used ones in the market; as well as determine the optimal brining levels that will lead to the lowest spoilage bacterial levels in frozen chicken portions.

\section{Materials and methods}

\section{Sources of experimental materials and laboratory analysis}

This research was carried out following the ethical approval given by the College of Agriculture and Environmental Sciences (CAES) research ethics review committee of University of South Africa (Ethics ref no: 2016/CAES/066). 180 freshly slaughtered broiler chickens from 3 different abattoirs (60 per abattoir) was used for this experiment. They were processed into chicken portions comprising of breasts, thighs and wings per chicken. These abattoirs were high through-put commercial poultry abattoirs, referred to as sources A, B and C. The standard plate, spore and psychrophilic bacterial count were carried out in a Biotechnology laboratory.

\section{Chicken sample preparation, chlorinated antimicrobial and brining applications at the abattoir}

The freshly slaughtered and processed mixed chicken portions from each abattoir was divided equally into 2 portions for antimicrobial intervention and brining. Three types of chlorinated antimicrobial were purchased from suppliers - Chlorine dioxide, Aqueous Chlorine, and Acidified Sodium Chlorite and applied at the rate of $50 \mathrm{mg} / \mathrm{g}$ to the chicken portions with brush (aseptically) after sub-dividing the portions into 3 equal 
parts aseptically. Thereafter, they were bagged into $1 \mathrm{~kg}$ cellophane bags and labelled for identification, and a total of 12 bags per abattoir were randomly selected for refrigeration, comprising of 4 bags per treatment. A total of 24 bags per plant was randomly selected, with 12 bags each for antimicrobial intervention and brining respectively, replicated 3 and 2 times per treatment accordingly. Chlorine antimicrobials - Aqueous Chlorine (Aq. Cl), Acidified Sodium Chlorite (ASC) and Chlorine Dioxide $\left(\mathrm{ClO}_{2}\right)$ all sprayed before packaging while the other 12 bags were assigned to 6 brining levels $(0 \%, 15 \%, 20 \%, 25 \%, 30 \%$, and $35 \%$ of $1 \mathrm{~kg}$ chicken portion) per treatment before quick freezing them for 6 months at $-10{ }^{\circ} \mathrm{C}$ and thawing thereafter for standard plate counts (SPC), spore counts and psychrophilic counts (log cfu/g).

The brine solutions were prepared in the abattoirs at the following brining concentration levels of $0 \%, 15 \%, 20 \%, 25 \%, 30 \%$ and $35 \%$ of $1 \mathrm{~kg}$ chicken portion as treatments (Table 1). The brine solutions were prepared separately for each brining level in stainless steel tanks that were automated and transported through a flexible hose to the brine injection unit. The processed portion per abattoir for brining were subsequently divided into 6 parts after weighing out $1 \mathrm{~kg}$ each, before brining and packaging in a cellophane bag and identified with an indelible marker. A total of 12 bags comprising of 2 bags per treatment were randomly selected for refrigeration at $10{ }^{\circ} \mathrm{C}$ for 6 months.

Table 1. Graded levels of brine mixes applied to each replicate of $1 \mathrm{~kg}$ chicken portion

\begin{tabular}{c|c|c|c|c|c|c}
\hline \multirow{2}{*}{ Ingredients } & \multicolumn{6}{|c}{ Brining (\%)* } \\
\cline { 2 - 7 } & $\mathbf{0}$ & $\mathbf{1 5}$ & $\mathbf{2 0}$ & $\mathbf{2 5}$ & $\mathbf{3 0}$ & $\mathbf{3 5}$ \\
\hline Salt (g) & 0 & 5.5 & 7.3 & 9.1 & 10.9 & 12.7 \\
Sugar (g) & 0 & 2.6 & 3.5 & 4.4 & 5.3 & 6.2 \\
Water (L) & 0 & 24.2 & 34.9 & 43.7 & 52.4 & 61.1 \\
\hline
\end{tabular}

${ }^{*}$ Chicken to brine ratio $=80: 20$ in percentage of $1 \mathrm{~kg}$

After 6 months of refrigeration, cold water thawing procedure at $26{ }^{\circ} \mathrm{C}$ was applied to thaw the samples. All of the frozen samples were firmly tied and placed in a leakproof plastic bag, before submerging in a sterile large bowl filled with water and allowed to thaw for $24 \mathrm{~h}$. The samples were then removed aseptically and sampled for standard plate counts (SPC), spore counts and psychrophilic counts (log CFU/g) in the laboratory which were recorded and analyzed for mean effects.

\section{Standard plate counts (SPC), spore counts and psychrophilic counts (log cfu/g)}

The procedure of Woteki (1998) was used to determine the microbiological quality by aseptically collected $(60 \pm 0.1 \mathrm{~g})$ of the sample (either the breast, wing or thigh randomly) from each replicate. The total plate count was conducted using the procedure of (AOAC, 1995). Psychrophilic bacterial count was carried out according to the procedure of (APHA, 2001). The counting was achieved using the same procedure as in Total Plate count; $1 \mathrm{ml}$ of the series dilutions, then the plates were incubated at $5-7^{\circ} \mathrm{C}$ for 10 days. The blended samples were then tested for standard plate counts (SPC), bacterial spores, coliform, staphylococci and yeast and molds by pour-plate method as per APHA (2001) procedures (Fig. 1). 


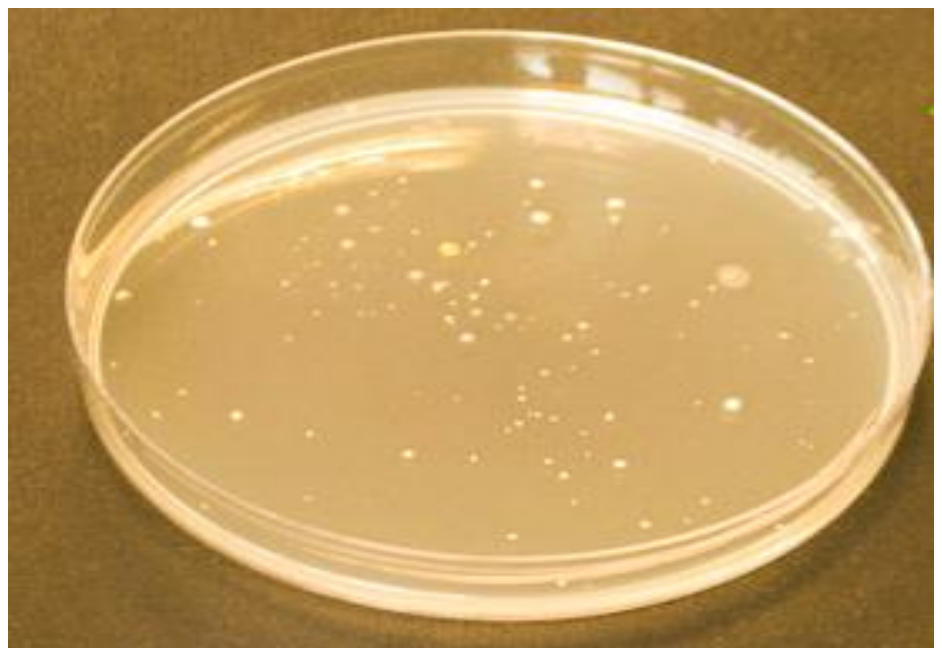

Figure 1. A petri dish showing a sample colony of psychrophilic bacteria from chicken portions rinsates using the procedure of APHA (2001)

\section{Statistical analysis}

The effects of source, antimicrobial intervention and brining levels on microbiological quality of chicken were analyzed with the general linear model (GLM) procedures of the (SPSS, 2017). The statistical model was:

$$
\mathrm{Y}_{\mathrm{ijk}}=\mu+\mathrm{T}_{\mathrm{i}}+\mathrm{B}_{\mathrm{j}}+\mathrm{C}_{\mathrm{k}}+(\mathrm{TB})_{\mathrm{ij}}+(\mathrm{TC})_{\mathrm{ik}}+\Sigma_{\mathrm{ijk}}
$$

where $\mathrm{Y}_{\mathrm{ijk}}=$ the overall observation (Bacterial load); $\mu=$ population means; $\mathrm{T}_{\mathrm{i}}=$ effect of abattoir source; $B_{j}=$ effect of antimicrobials; $C_{k}=$ effect of brining levels; $(\mathrm{TB})_{\mathrm{ij}}=$ interaction effect of abattoir source and antimicrobials; $(\mathrm{TC})_{\mathrm{ik}}=$ interaction effects of abattoir source and brining and $\Sigma_{\mathrm{ijk}}=$ residual effect.

A breakdown of the experimental design is as shown below:

Treatment $1=$ Abattoirs effects only

Treatment $2=$ Antimicrobial effects only

Treatment $3=$ Brining effects only

Treatment $4=$ Abattoirs and antimicrobial agents.

Treatment $5=$ Abattoirs and brining levels

Where there was a significant F-test $(\mathrm{P}<0.05)$, the Duncan New Multiple Range test method was used to separate the means according to SPSS (2017).

The related responses in Psychrophilic bacterial count to antimicrobial and brining levels were modeled using the quadratic regression model below:

$$
Y=a+b_{1} x+b_{2} x^{2}
$$

where $\mathrm{Y}=$ microbiological load; $\mathrm{a}=$ intercepts on $\mathrm{Y}$ axis; $\mathrm{b}=$ co-efficient of the quadratic equation; $x=$ brining levels in percentages and $b_{1} / 2 b_{2}=x$ value for optimal or minimal responses. The quadratic model was fitted to the experimental data by means of the regression using curve estimation procedure of SPSS (2017). The quadratic model was used because it gave the best fit (Okoro and Mbajiorgu, 2017). 


\section{Results}

The application of chlorine antimicrobials had a significant effect $(\mathrm{P}<0.05)$ on the chicken portions from within abattoirs used in the study (Table 2), they however did not differ between different abattoirs within treatments. Although the values of samples treated with acidified sodium chlorite were consistently lower in all the samples from different abattoirs than those treated with aqueous chlorine and chlorine dioxide, no statistical significant differences were recorded between them. However, between the three chlorine antimicrobials, the ASC consistently recorded a significantly lowest SPC, spores and psychrophilic bacterial count while Aq. $\mathrm{Cl}$ recorded the highest $(\mathrm{P}<0.05)$ But there were no significant difference between values of spore counts generated from abattoir $\mathrm{C}$. This could be due to all three antimicrobials being made from chlorine, resulting in their effectiveness appearing to be the same in terms of reducing standard plate counts (SPC), spore counts and psychrophilic counts.

Table 2. Effects of chlorine antimicrobials on standard plate count, spores and psychrophilic bacteria count (logCFU/g) of frozen chicken from 3 commercial chicken abattoirs sampled

\begin{tabular}{c|c|c|c|c|c|c}
\hline \multirow{2}{*}{$\begin{array}{c}\text { Microbial* } \\
\text { counts } \\
(\log \text { CFU/g) }\end{array}$} & \multirow{2}{*}{ Abattoirs } & \multicolumn{5}{|c}{ Chlorine antimicrobials (50 mg/g) } \\
\cline { 3 - 7 } & & ASC & Aq. Cl. & ClO $_{2}$ & SEM & P-Value \\
\hline \multirow{3}{*}{ SPC } & A & $1.33^{\mathrm{c}}$ & $2.50^{\mathrm{b}}$ & $2.98^{\mathrm{a}}$ & 0.189 & 0.030 \\
& $\mathrm{~B}$ & $1.33^{\mathrm{c}}$ & $2.67^{\mathrm{b}}$ & $2.92^{\mathrm{a}}$ & 0.221 & 0.029 \\
& $\mathrm{C}$ & $1.17^{\mathrm{c}}$ & $2.92^{\mathrm{b}}$ & $3.11^{\mathrm{a}}$ & 0.367 & 0.045 \\
\hline \multirow{3}{*}{ Spores } & $\mathrm{A}$ & $1.36^{\mathrm{c}}$ & $2.72^{\mathrm{b}}$ & $3.18^{\mathrm{a}}$ & 0.379 & 0.050 \\
& $\mathrm{~B}$ & $1.37^{\mathrm{c}}$ & $3.07^{\mathrm{b}}$ & $3.22^{\mathrm{a}}$ & 0.221 & 0.052 \\
& $\mathrm{C}$ & 2.76 & 3.02 & 3.21 & 0.367 & 0.560 \\
\hline \multirow{3}{*}{ Psychrophiles } & $\mathrm{A}$ & $1.37^{\mathrm{c}}$ & $2.60^{\mathrm{b}}$ & $2.98^{\mathrm{a}}$ & 0.389 & 0.030 \\
& $\mathrm{~B}$ & $1.51^{\mathrm{c}}$ & $2.57^{\mathrm{b}}$ & $2.92^{\mathrm{a}}$ & 0.321 & 0.034 \\
& $\mathrm{C}$ & $1.42^{\mathrm{c}}$ & $2.52^{\mathrm{b}}$ & $3.09^{\mathrm{a}}$ & 0.467 & 0.025 \\
\hline
\end{tabular}

a,b,c Means in the same row and column not sharing a common superscript are significantly different $(\mathrm{P}<0.05) \mathrm{SEM}=$ standard error of mean, $\mathrm{P}$ - value = probability value, $\mathrm{Aq} . \mathrm{CI}=$ aqueous chlorine, $\mathrm{ASC}$ $=$ acidified sodium chlorite, $\mathrm{CIO}_{2}=$ chlorine dioxide

The effect of the brining levels on standard plate count, spores and psychrophilic bacterial count was the same across all three major abattoirs (Table 3). However, at $0 \%$ brine, the microbiological quality was significantly higher $(\mathrm{P}<0.05)$ than any other levels in all three abattoirs. Furthermore, the results have indicated no significant difference of SPC, spores and psychrophilic bacterial count between 15, 20 and 25\% across all samples from the three abattoirs. The brining levels between 30 and $35 \%$ also has no significant differences $(\mathrm{P}<0.05)$ among them for the microbial loads.

The levels of brining and chlorine antimicrobials affected the levels of standard plate count, spores and psychrophilic bacterial load in the frozen chicken portions (Table 4). The control samples $(0 \%$ brine $)$ had significantly higher $(\mathrm{P}<0.05)$ bacterial load than all samples injected with various brining levels. At $20 \%$ and $25 \%$ brining levels however, there was no difference $(\mathrm{P}>0.05)$ in bacterial count except for SPC where $20 \%$ is significantly higher than $25 \%$.

Application of quadratic regression model to identify optimal brining levels to achieve the least SPC, spore and psychrophilic bacterial count resulted in a significant 
( $\mathrm{P}<0.05$ ) optimum levels (Table 5). The effect of percentage brining on average SPC, spore and psychrophilic bacteria count had optimum quadratic values of $20.67+20.578$ brining -7.986 brining $^{2}, 80.142-31.793$ brining +2.178 brining $^{2}$ and $31.77+5.909$ brining - 3.748 brining $^{2}$ respectively. The optimal brining levels were 13.27, 35.87 and 34.10 for SPC, spore and psychrophilic counts respectively. These are the optimal brining level to give the lowest microbial count in 6 months frozen $\left(-10 \pm 2{ }^{\circ} \mathrm{C}\right)$ chicken portions. The co-efficient of determination $\left(\mathrm{R}^{2}\right)$ which is very high, implies that the optimum brining levels have significant influence in reducing microbial load.

The result of the optimization function indicates that brining has a direct effect on the amount of microbial counts that develop during long term refrigeration; hence, the best brining level of inclusion to achieve the fewest number of bacterial loads is determined (Figs. 2 and 3).

Table 3. Effects of brining levels on standard plate count, spores and Psychrophilic bacteria count (logCFU/g) of frozen chicken from 3 commercial chicken abattoirs sampled

\begin{tabular}{c|c|c|c|c|c|c|c|c|c}
\hline \multirow{2}{*}{$\begin{array}{c}\text { Microbial* } \\
\text { counts } \\
\text { (logCFU/g) }\end{array}$} & \multirow{2}{*}{ Abattoirs } & \multicolumn{7}{|c}{ Brining levels (\%) } \\
\cline { 3 - 9 } & & $\mathbf{0}$ & $\mathbf{1 5}$ & $\mathbf{2 0}$ & $\mathbf{2 5}$ & $\mathbf{3 0}$ & $\mathbf{3 5}$ & SEM & P-value \\
\hline \multirow{3}{*}{ SPC } & $\mathrm{A}$ & $3.23^{\mathrm{a}}$ & $2.67^{\mathrm{b}}$ & $2.27^{\mathrm{bc}}$ & $2.11^{\mathrm{c}}$ & $1.92^{\mathrm{d}}$ & $1.33^{\mathrm{d}}$ & 0.352 & 0.001 \\
& $\mathrm{~B}$ & $3.00^{\mathrm{a}}$ & $2.33^{\mathrm{b}}$ & $2.19^{\mathrm{c}}$ & $2.09^{\mathrm{c}}$ & $1.89^{\mathrm{d}}$ & $1.67^{\mathrm{d}}$ & 0.584 & 0.001 \\
& $\mathrm{C}$ & $3.13^{\mathrm{a}}$ & $1.97^{\mathrm{b}}$ & $2.33^{\mathrm{bc}}$ & $2.12^{\mathrm{c}}$ & $1.87^{\mathrm{d}}$ & $1.17^{\mathrm{d}}$ & 0.419 & 0.001 \\
\hline \multirow{3}{*}{ Spores } & $\mathrm{A}$ & $3.18^{\mathrm{a}}$ & $2.47^{\mathrm{b}}$ & $2.28^{\mathrm{bc}}$ & $2.10^{\mathrm{c}}$ & $1.89^{\mathrm{d}}$ & $1.23^{\mathrm{d}}$ & 0.552 & 0.021 \\
& $\mathrm{~B}$ & $3.25^{\mathrm{a}}$ & $2.43^{\mathrm{b}}$ & $2.27^{\mathrm{c}}$ & $2.11^{\mathrm{c}}$ & $1.88^{\mathrm{d}}$ & $1.56^{\mathrm{d}}$ & 0.444 & 0.035 \\
& $\mathrm{C}$ & $3.30^{\mathrm{a}}$ & $2.52^{\mathrm{b}}$ & $2.25^{\mathrm{bc}}$ & $2.08^{\mathrm{c}}$ & $1.90^{\mathrm{d}}$ & $1.47^{\mathrm{d}}$ & 0.319 & 0.033 \\
\hline \multirow{2}{*}{ Psychrophiles } & $\mathrm{A}$ & $3.93^{\mathrm{a}}$ & $3.17^{\mathrm{b}}$ & $2.87^{\mathrm{bc}}$ & $2.21^{\mathrm{c}}$ & $1.52^{\mathrm{d}}$ & $1.13^{\mathrm{d}}$ & 0.252 & 0.041 \\
& $\mathrm{~B}$ & $3.60^{\mathrm{a}}$ & $3.33^{\mathrm{b}}$ & $2.79^{\mathrm{c}}$ & $2.14^{\mathrm{c}}$ & $1.69^{\mathrm{d}}$ & $1.07^{\mathrm{d}}$ & 0.384 & 0.044 \\
& $\mathrm{C}$ & $4.13^{\mathrm{a}}$ & $2.97^{\mathrm{b}}$ & $2.43^{\mathrm{bc}}$ & $2.02^{\mathrm{c}}$ & $1.47^{\mathrm{d}}$ & $1.11^{\mathrm{d}}$ & 0.219 & 0.026 \\
\hline
\end{tabular}

a,b,c Means in the same row and column not sharing a common superscript are significantly different $(\mathrm{P}<0.05) . \mathrm{SEM}=$ standard error of mean, $\mathrm{P}$-value $=$ probability value, $\mathrm{CLO}_{2}=$ chlorine dioxide, Aq. $\mathrm{CI}$ $=$ aqueous chlorine, $\mathrm{ASC}=$ acidified sodium chlorite

Table 4. Effects of antimicrobial intervention and brining on microbial counts of mixed chicken portions frozen $\left(-10^{\circ} \mathrm{C} \pm 2\right)$ for 6 months

\begin{tabular}{|c|c|c|c|c|c|c|c|c|c|c|c|}
\hline \multirow{2}{*}{$\begin{array}{l}\text { Microbial* } \\
\text { counts } \\
(\log C F U / g)\end{array}$} & \multicolumn{3}{|c|}{$\begin{array}{c}\text { Antimicrobial } \\
\text { intervention* }(50 \mathrm{mg} / \mathrm{g})\end{array}$} & \multicolumn{6}{|c|}{ Brining (\%) } & \multirow[t]{2}{*}{ SEM } & \multirow[t]{2}{*}{ P-value } \\
\hline & ASC & Aq. Cl. & $\mathrm{ClO}_{2}$ & 0 & 15 & 20 & 25 & 30 & 35 & & \\
\hline SPC & $1.17^{\mathrm{c}}$ & $2.52^{\mathrm{b}}$ & $3.21^{\mathrm{a}}$ & $3.33^{\mathrm{a}}$ & $2.87^{\mathrm{b}}$ & $2.63^{\mathrm{b}}$ & $2.32^{\mathrm{c}}$ & $1.76^{\mathrm{d}}$ & $1.57^{\mathrm{d}}$ & 0.267 & 0.023 \\
\hline Spores & $1.47^{\mathrm{c}}$ & $3.01^{\mathrm{b}}$ & $3.42^{\mathrm{a}}$ & $3.25^{\mathrm{a}}$ & $2.43^{\mathrm{b}}$ & $2.12^{\mathrm{c}}$ & $2.11^{\mathrm{c}}$ & $1.87^{\mathrm{d}}$ & $1.56^{\mathrm{d}}$ & 0.412 & 0.044 \\
\hline sychrophilic & $1.39^{c}$ & $2.30^{\mathrm{b}}$ & $3.08^{\mathrm{a}}$ & $3.63^{\mathrm{a}}$ & $3.32^{\mathrm{b}}$ & $2.40^{\mathrm{c}}$ & $2.13^{\mathrm{c}}$ & $1.70^{\mathrm{d}}$ & $1.06^{\mathrm{d}}$ & 0.321 & 0.001 \\
\hline
\end{tabular}

a,b,c Means in the same row not sharing a common superscript are significantly different $(\mathrm{P}<0.05)$. $\mathrm{SEM}=$ standard error of mean, $\mathrm{P}$-value $=$ probability value, $\mathrm{Aq} . \mathrm{CI}=$ aqueous chlorine, $\mathrm{ASC}=$ acidified sodium chlorite, $\mathrm{CIO}_{2}=$ chlorine dioxide, $* \mathrm{SPC}=$ standard plate count, $\mathrm{ASC}=$ acidified sodium chlorite, Aq. $\mathrm{CI}=$ aqueous chlorine, $\mathrm{CIO}_{2}=$ chlorine dioxide 
Table 5. The optimal brining levels on standard plate count, spores and psychrophilic bacteria count (logCFU/g) using quadratic regression model

\begin{tabular}{c|c|c|c|c}
\hline $\begin{array}{c}\text { Microbial* } \\
\text { counts } \\
\text { (logCFU/g) }\end{array}$ & $\mathbf{R}^{2}$ values & Optimal Y levels of bacteria & Optimal brining levels (\%) & P - Value \\
\hline SPC & 0.988 & 1.289 & 13.27 & 0.001 \\
Spore & 0.980 & 7.299 & 35.87 & 0.003 \\
Psychrophile & 0.938 & 0.788 & 34.10 & 0.016 \\
\hline
\end{tabular}

$\mathrm{SPC}=$ standard plate count, $\mathrm{R}^{2}=$ co-efficient of determination, $\mathrm{P}$-value = probability value

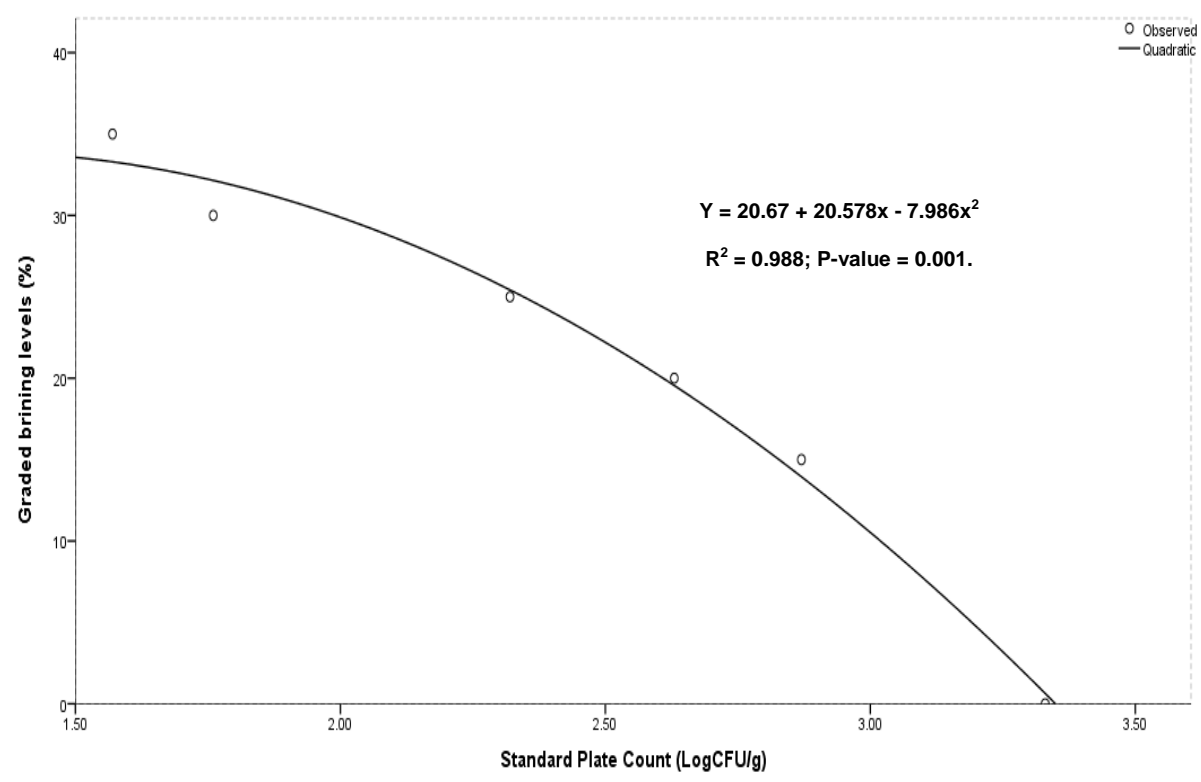

Figure 2. Quadratic function showing the optimum brining levels of quick frozen chicken for standard plate count

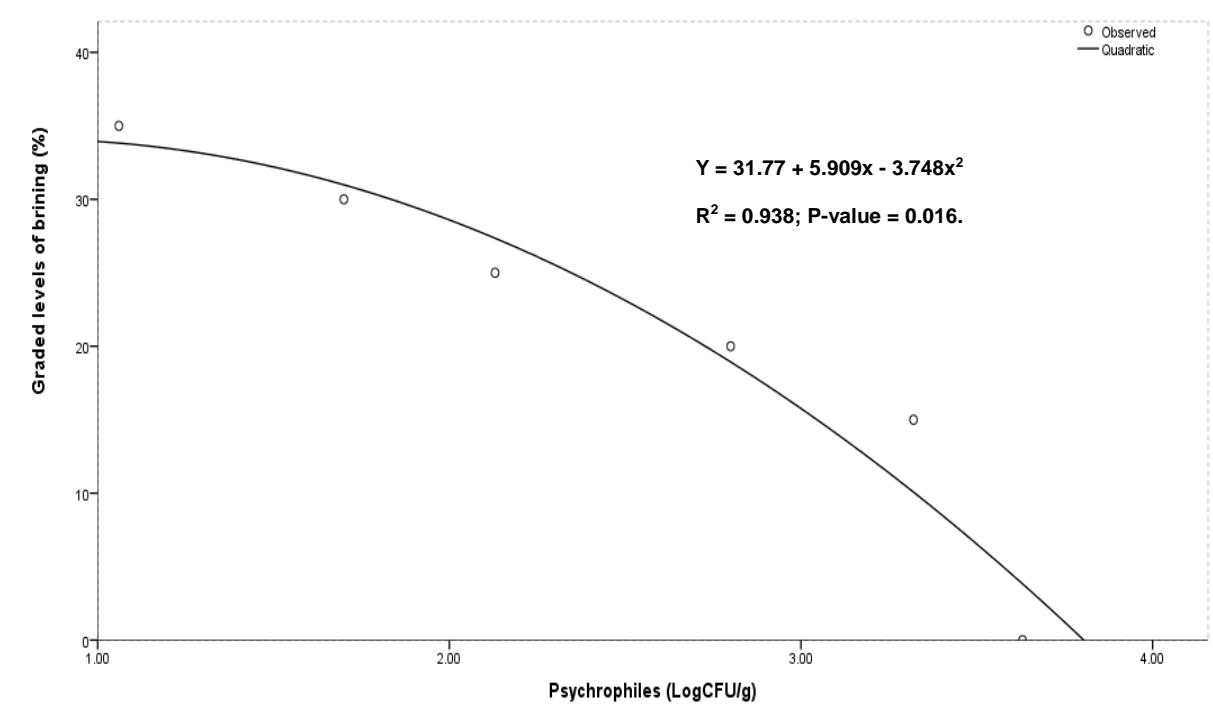

Figure 3. Quadratic function showing the optimum brining levels of quick frozen chicken for psychrophilic bacterial count 


\section{Discussion}

Antimicrobial intervention and brining of chicken portions are important in preservation and storage of meat as Perez-Chabela and Mateo-Oyague (2004) reported that pathogenic microorganisms are commonly isolated from thawed frozen raw meat with larvae of Taenia spp. and Trichinella spiralis killed after 1-3 weeks of refrigeration at $-18{ }^{\circ} \mathrm{C}$ or after ultra-rapid freezing at $-29^{\circ} \mathrm{C}$ of raw meat. Also Lowry and Gill (1984) reported that moulds grew at temperatures lower than $-10^{\circ} \mathrm{C}$ with Knøchel et al. (2007) also reporting the development of spoilage microbes in non-marinated chicken which increases rapidly when refrigerated. Chlorine is a major antimicrobial intervention agent and its widely used in poultry processing industry being effective against a whole range of microorganism in poultry processing (Purnell et al., 2014) and is regarded as the most effective antimicrobial to control bacterial, viral and protozoan pathogens (Duan et al., 2017; Purnell et al., 2014). However, it is reported that the efficacy of the antimicrobials is determined by the level of attachment of bacterial infection on the chicken skin. This factor might have a slight contribution to the results as the samples were sprayed directly on each sample before the portions were packed. It is reported that chlorine dioxide, when used under commercial operations, has the potential to reduce up to 2- $3 \log \mathrm{CFU} / \mathrm{g}$ in microbial levels in frozen poultry (Tamblyn and Conner, 1997). The present study indicates that all the abattoirs were not affected by the effects of the antimicrobials when they were compared. However, among the antimicrobials, there was a significant difference in terms of the microbial load of the samples tested with acidified sodium chlorite having the least load while chlorine dioxide having the most load. Although all three chosen antimicrobials originated from chlorine as a base, acidified sodium that reduced more bacteria than all other antimicrobials is in acidic format, a form which is very convenient to lactic acid bacteria that is capable of causing great reduction of microbial load in white meat (Oyarzabal, 2008; Vlahova-Vangelova and Dragoev, 2014). This is also in agreement with the findings of Purnell et al. (2014) showing that acidified sodium chloride could be the most effective antimicrobial to be used in the poultry processing industry.

Brining of chicken slows formation of colony for spoilage bacteria and the bacterial development remains below $1.03 \log$ CFU/g (Knøchel et al., 2007; Vlahova-Vangelova and Dragoev, 2014) for a period of 3 months. Different amounts of brine required for use in chicken preservation has been reported by different authors. Alvarado and McKee (2007) reported that salt within brine was meant to reduce rate of deterioration by reducing the growth of microorganisms in the chicken with higher concentration of salt proven to inhibit the microbial spoilage in white meat. This study has shown that higher level of brining consistently reduces the levels of microbial organisms causing spoilage. Although 5\% brine is reported for best quality of meat products when assessing the chicken from sensory properties (Venter, 2015); it did not consider levels of spoilage microbes effect on the meat due to longer periods of storage. This study has shown that at lower levels of inclusion of brine (0-10\%), the level of spoilage microbes is still within safe limits after 6 months of refrigeration, implying that higher levels might not be necessary. But as the period of refrigeration increases beyond 6 months, the spoilage bacteria level could increase, hence The United States Food and Drug Administration (USFDA) recommended a storage period of 9 months for chicken and turkey parts (FDA, 2017). Meanwhile, Venter (2015) reported the prohibition of abattoirs from exceeding $15 \%$ level of brining by the country's regulatory body resulting in a suggested $20 \%$ brining levels by the abattoirs as the most accommodative 
amount for inclusion when considering longer preservation periods. This study however suggests an inclusion of up to $34.10 \%$ brining level to optimally remove psychrophilic microbes, and 13.27 for optimal eradication of standard plate count of microbes. Brining at levels up to $60 \%$ may reduce the quality of the chicken through dilution of nutrients such as proteins, fat and energy (Tamblyn and Conner, 1997; Whitman and Marshall, 1971). Farber and Idziak (1984) had reported high moisture content in the $60 \%$ brining level treated samples resulting in lower salt which has been diluted by the moisture. However, Farber and Idziak (1984) reported that the highest injection level of $60 \%$ was tenderer than lower inclusion levels.

The primary preservation agents of brine are salt and sugar, which do not only prevent spoilage of the chicken but serve to inhibit growth of pathogens and spoilage bacteria when applied correctly (Pichpol, 2009; Purnell et al., 2014). These preservative agents have antimicrobial mechanisms which capacitate them to disrupt microbial enzyme activity and weaken their DNA structure. Sugar's preservative mechanism is to accelerate accumulation of antimicrobial compounds from the growth of spoilage microorganisms. This includes conversion of sugar molecules to organic acids by lactic acid bacteria (Vlahova-Vangelova and Dragoev, 2014). Moreover, Vlahova-Vangelova and Dragoev (2014) had reported that development of spoilage bacteria depend on the presence of lactic acid bacteria solutions not sugars. This may explain why the greatest reduction of spoilage microbes is found between 30-35\% of brining level in this study.

\section{Conclusion}

Generally, this study has shown that usage of antimicrobial intervention and brining could achieve the same level of microbial reduction, hence either of the two could be used when preserving chicken portions. An antimicrobial intervention of acidified sodium chlorite could be used in the preservation of chicken portions, while brining up to the level of $13.27 \%$ for reduced standard plate count and $34.10 \%$ for optimum psychrophilic bacterial count reduction could be important. Therefore, ASC could be used interchangeably while brining, as it is easily accessible in the market and relatively cheap, making it a better preservative commercially for chicken preservation than other antimicrobials.

Acknowledgements. The authors wish to acknowledge the active participation of the meat processing plants that allowed the use of their facilities in conducting this experiment.

\section{REFERENCES}

[1] Alonso-Hernando, A., Alonso-Calleja, C., Capita, R. (2013): Effectiveness of several chemical decontamination treatments against Gram-negative bacteria on poultry during storage under different simulated cold chain. - Food Control 34: 574-580.

[2] Alvarado, C., McKee, S. (2007): Marination to improve functional properties and safety of poultry meat. - Journal of Applied Poultry Research 16: 113-120.

[3] AOAC (1995): Official Methods of Analysis. - Association of Official Analytical Chemists, Washington DC.

[4] APHA (2001): Compendium of Methods for the Microbiological Examination of Food. American Public Health Association, Washington DC. 
[5] Cassens, R. G. (1994): Meat Preservation Preventing Losses and Assuring Safety. Departement of Meat and Animal Sciences. - University of Wisconsin, Food and Nutrition Press, Inc, Madison, WI.

[6] Duan, D., Wang, H., Xue, S., Li, M., Xu, X. (2017): Application of disinfectant sprays after chilling to reduce the initial microbial load and extend the shelf-life of chilled chicken carcasses. - Food Control 75: 70-77.

[7] Ellinger, R. (1972): Phosphates in Food Processing. - In: Furia, T. E. (ed.) Handbook of Food Additives. CRC, Boca Raton, FL, pp. 617-780.

[8] Ercolini, D., Russo, F., Blaiotta, G., Pepe, O., Mauriello, G., Villani, F. (2007): Simultaneous detection of Pseudomonas fragi, P. lundensis, and P. putida from meat by use of a multiplex PCR assay targeting the carA gene. - Applied and Environmental Microbiology 73: 2354-2359.

[9] Farber, J. M., Idziak, E. S. (1984): Attachment of psychrotrophic meat spoilage bacteria to muscle surfaces. - Journal of Food Protection 47: 92-95.

[10] FDA (2017): Food Code. - U. S. Public Health Services of US Food and Drug Administration, College Park, MD.

[11] Holzapfel, W. (1998): The Gram-positive bacteria associated with meat and meat products. - The Microbiology of Meat and Poultry 31: 35-74.

[12] Knøchel, S., Mach, N., Karlsson, A. (2007): Microbial and physical changes in marinated beef of high and normal $\mathrm{pH}$ during storage in different atmospheres. - International $53^{\text {rd }}$ Congress of Meat Science and Technology, Beijing, 5-10 August, pp. 37-38.

[13] Lowry, P. D., Gill, C. O. (1984): Mould growth on meat at freezing temperatures. - Int. J. Refrigeration 7: 133-136. https://doi.org/DOI: 10.1016/0140-7007(84)90026-4.

[14] Modi, V. K., Sachindra, N. M., Sathisha, A. D., Mahendrakar, N. S., Narasimha Rao, D. (2006): Changes in quality of chicken curry during frozen storage. - Journal of Muscle Foods 17: 141-154. https://doi.org/10.1111/j.1745-4573.2006.00034.x.

[15] Neumeyer, K., Ross, T., Thomson, G., McMeekin, T. A. (1997): Validation of a model describing the effects of temperature and water activity on the growth of psychrotrophic pseudomonads. - International Journal of Food Microbiology 38: 55-63.

[16] Nychas, G., Drosinos, E., Board, R. (1998): Chemical Changes in Stored Meat. - In: Board, R. J., Cavies, A. R. (eds.) Microbiology of Meat and Poultry. Springer, New York.

[17] Okoro, V. M. O., Mbajiorgu, C. A. (2017): Crossbreeding parameter estimates for growth and conformation traits in a three pig diallel cross. - Applied Ecology and Environmental Research 15: 117-128. http://dx.doi.org/10.15666/aeer/1504_117128.

[18] Oyarzabal, O. (2008): Antimicrobials to control Campylobacter in broilers. - Department of Poultry Science. MSc Dissertation, Auburn University, USA.

[19] Perez-Chabela, M. L., Mateo-Oyague, J. (2004): Frozen Meat: Quality and Shelf Life. In: Hui, Y. H., Cornillon, P., Legaretta, I. G., Lim, M. H., Murrell, K. D., Kit Nip, W. (eds.) Handbook of Frozen Foods. Marcel Dekker Inc, New York.

[20] Pichpol, D. (2009): Experimental reduction of salmonella in raw chicken breasts. - MSc Dissertation, Faculty of Veterinary and Animal Sciences, Freien University, Berlin.

[21] Purnell, G., James, C., James, S., Howell, M., Corry, J. (2014): Comparison of acidified sodium chlorite, chlorine dioxide, peroxyacetic acid and tri-sodium phosphate spray washes for decontamination of chicken carcasses. - Food and Bioprocess Technology 7: 2093-2101.

[22] Rahman, S. F. (1999): Food Preservation by Freezing. - In: Rahman, S. F. (ed.) Handbook of Food Preservation. Marcel Dekker, New York, pp: 259, 262, 268.

[23] SPSS (2017): IBM SPSS Statistics Software 24. - IBM, Armonk, NY.

[24] Sudheer, K., Das, C., Mandal, P. K., Pal, U., Rao, V. (2011): Effect of frozen storage on the physico-chemical, microbiological and sensory quality of low fat restructured chicken block incorporated with gizzard. - International Journal of Meat Science 1: 62-69. 
[25] Tamblyn, K., Conner, D. (1997): Bactericidal activity of organic acids in combination with transdermal compounds against Salmonella typhimurium attached to broiler skin. Food Microbiology 14: 477-484.

[26] Van Berkel, B. M., Boogaard, B., Heijnen, C. (2004): Preservation of Fish and Meat. Technical Centre for Agricultural and Rural Co-operation, Agromisa Foundation, Wageningen.

[27] Venter, Z. (2015): Bid to halt chicken brine regulations fails. - IOL News. https://www.iol.co.za/news/bid-to-halt-chicken-brine-regulations-fails-2071194.

[28] Vlahova-Vangelova, D., Dragoev, S. (2014): Marination: effect on meat safety and human health. A review. - Bulgarian Journal of Agricultural Science 20: 503-509.

[29] Whitman, P. A., Marshall, R. T. (1971): Isolation of psychrophilic bacteriophage-host systems from refrigerated food products. - Applied Microbiology 22: 220-223.

[30] Woteki, C. (1998): USDA FSIS: Food Safety Research Priorities and Challenges. - Food Safety and Inspection Service, United States Department of Agriculture Washington, DC.

[31] Xia, X., Kong, B., Liu, Q., Liu, J. (2009): Physicochemical change and protein oxidation in porcine Longissimus dorsi as influenced by different freeze-thaw cycles. - Meat Science 83: 239-245.

[32] Zhou, G. H., Xu, X. L., Liu, Y. (2010): Preservation technologies for fresh meat. A review. - Meat Science 86: 119-128.

\section{APPENDIX}

\section{OUTPUTS FROM SPSS2017}

ANOVA for independent variable: chlorine antimicrobials and abattoirs for SPC, spore count and psychrophilic bacterial count

$S P C$

\begin{tabular}{c|c|c|c|c|c|c|c|c|c}
\hline \multicolumn{1}{l|}{ ABT } & ATM2 & N & Mean & Std. dev. & Std. error & \multicolumn{2}{c|}{ D5\% confidence interval for } & \multirow{2}{*}{ mean } & \multirow{2}{*}{ Max } \\
\cline { 8 - 9 } & & & & & Lower bound & Upper bound & & \\
\hline A & 1.00 & 12 & 1.33072 & 3.12856 & .189034 & 1.1789 & 1.1545 & 1.1789 & 1.4545 \\
\hline A & 2.00 & 12 & 2.5012 & 4.31611 & .224595 & 1.1743 & 1.6590 & 2.1743 & 2.6590 \\
\hline A & 3.00 & 12 & 2.98324 & 4.26046 & .367299 & 1.4597 & 1.8736 & 2.4597 & 3.2396 \\
\hline & Pr. & .87 & .0301 & 3.76552 & .073 & 1.933 & .004 & .9822 & .3236 \\
\hline & Total & 36 & 2.45500 & .00268 & .66711 & 1.3957 & 1.1043 & 2.00 & 3.00 \\
\hline B & 1.00 & 12 & 1.33072 & 2.12856 & .19034 & 1.3789 & 1.1545 & 1.1789 & 1.545 \\
\hline B & 2.00 & 12 & 2.6712 & 3.10611 & .324595 & 1.7743 & 1.6590 & 2.1743 & 2.5590 \\
\hline B & 3.00 & 12 & 2.92445 & 3.30046 & .465299 & 1.3797 & 1.8736 & 2.4597 & 3.0391 \\
\hline & Pr. & .87 & .02901 & .34552 & .303 & 1.633 & .005 & .9812 & .13226 \\
\hline & Total & 36 & 2.3510 & 4.1268 & .86711 & 1.2157 & 1.2043 & 1.40 & 2.780 \\
\hline C & 1.00 & 12 & 1.17204 & 2.89856 & .179034 & 1.3289 & 1.2345 & 1.2739 & 1.2545 \\
\hline C & 2.00 & 12 & 2.9212. & 3.71611 & .52595 & 1.3443 & 1.4290 & 2.2243 & 2.1190 \\
\hline C & 3.00 & 12 & 3.11324 & 3.62046 & .26299 & 1.1957 & 1.3436 & 2.8507 & 3.2766 \\
\hline & Pr. & .87 & .045201 & .76552 & .003 & .933 & .054 & .9822 & .2136 \\
\hline & Total & 36 & 2.65500 & 4.00268 & .66711 & 1.3057 & 1.2043 & 2.100 & 3.00 \\
\hline
\end{tabular}




\begin{tabular}{l|c|c|c|c|c|c}
\hline & \multicolumn{7}{c}{ ANOVA } & Sig. \\
\hline & ATM2 & Sum of squares & df & Mean square & F & .025 \\
\hline & Between groups & 48.500 & 17 & 24.250 & 1.562 & \\
\hline & Within groups & 512.250 & 35 & 15.523 & & \\
\hline & Total & 560.750 & 52 & & & \\
\hline
\end{tabular}

$1=\mathrm{ASC}, 2=\mathrm{AQ} . \mathrm{CL}, 3=\mathrm{CLO} 2, \mathrm{ATM}=$ Antimicrobial intervention, $\mathrm{ABT}=$ Abattoir

SPORES

\begin{tabular}{|c|c|c|c|c|c|c|c|c|c|}
\hline \multicolumn{10}{|c|}{ Descriptive } \\
\hline \multirow[t]{2}{*}{ ABT } & \multirow[t]{2}{*}{ ATM2 } & \multirow[t]{2}{*}{$\mathbf{N}$} & \multirow[t]{2}{*}{ Mean } & \multirow[t]{2}{*}{ Std. dev. } & \multirow{2}{*}{ Std. error } & \multicolumn{2}{|c|}{$\begin{array}{c}95 \% \text { confidence interval for } \\
\text { mean }\end{array}$} & \multirow[t]{2}{*}{ Min. } & \multirow[t]{2}{*}{ Max } \\
\hline & & & & & & Lower bound & Upper bound & & \\
\hline $\mathrm{A}$ & 1.00 & 12 & 1.37233 & 3.12856 & .191034 & 1.2789 & 1.6545 & 1.2789 & 1.2545 \\
\hline $\mathrm{A}$ & 2.00 & 12 & 2.7212 & 4.21611 & .324595 & 1.5543 & 1.8910 & 2.5743 & 2.4590 \\
\hline \multirow[t]{3}{*}{ A } & 3.00 & 12 & 3.18324 & 4.23046 & .417299 & 1.4976 & 1.9936 & 2.8597 & 3.1396 \\
\hline & Pr. & .87 & .0501 & 3.36552 & .093 & 1.7303 & .024 & .5822 & .4246 \\
\hline & Total & 36 & 2.67500 & .03268 & .46711 & 1.4157 & 1.2043 & 1.90 & 2.170 \\
\hline B & 1.00 & 12 & 1.37202 & 2.33856 & .29034 & 1.1789 & 1.2545 & 1.1289 & 1.745 \\
\hline $\mathrm{B}$ & 2.00 & 12 & 3.0712 & 3.00611 & .34595 & 1.2743 & 1.4390 & 2.1243 & 2.990 \\
\hline \multirow[t]{3}{*}{$\mathrm{B}$} & 3.00 & 12 & 3.22445 & 3.29046 & .40299 & 1.4797 & 1.9736 & 2.9197 & 3.4391 \\
\hline & Pr. & .87 & .0521 & .324552 & .3503 & 1.833 & .2005 & .9212 & .12226 \\
\hline & Total & 36 & 2.3510 & 4.1268 & .86711 & 1.2157 & 1.2043 & 1.40 & 3.780 \\
\hline $\mathrm{C}$ & 1.00 & 12 & 2.7604 & 2.89856 & .179034 & 1.3289 & 1.2345 & 1.2739 & 1.2545 \\
\hline $\mathrm{C}$ & 2.00 & 12 & 3.0212 & 3.71611 & .52595 & 1.3443 & 1.4290 & 2.2243 & 2.1190 \\
\hline \multirow[t]{3}{*}{$\mathrm{C}$} & 3.00 & 12 & 3.21324 & 3.62046 & .26299 & 1.1957 & 1.3436 & 2.8507 & 3.2766 \\
\hline & Pr. & .87 & .045201 & .76552 & .003 & .933 & .054 & .9822 & .2136 \\
\hline & Total & 36 & 2.15500 & 4.00268 & .66711 & 1.3057 & 1.2043 & 2.100 & 3.00 \\
\hline
\end{tabular}

\begin{tabular}{c|c|c|c|c|c|c}
\hline & \multicolumn{7}{|c}{ ANOVA } & Sig. \\
\hline & ATM2 & Sum of squares & df & Mean square & F & .015 \\
\hline & Between groups & 55.300 & 17 & 124.250 & 1.62 & \\
\hline & Within groups & 432.870 & 35 & 418.523 & & \\
\hline & Total & 487.170 & 52 & & & \\
\hline
\end{tabular}

\section{PSYCHROPHILES}

\begin{tabular}{|c|c|c|c|c|c|c|c|c|c|}
\hline \multirow{3}{*}{ ABT } & \multicolumn{9}{|c|}{ Descriptive } \\
\hline & \multirow[t]{2}{*}{ ATM2 } & \multirow[t]{2}{*}{$\mathbf{N}$} & \multirow[t]{2}{*}{ Mean } & \multirow[t]{2}{*}{ Std. dev. } & \multirow[t]{2}{*}{ Std. error } & \multicolumn{2}{|c|}{$\begin{array}{l}\text { 95\% confidence interval for } \\
\text { mean }\end{array}$} & \multirow[t]{2}{*}{ Min. } & \multirow[t]{2}{*}{$\operatorname{Max}$} \\
\hline & & & & & & Lower bound & Upper bound & & \\
\hline $\mathrm{A}$ & 1.00 & 12 & 1.37211 & 3.02856 & .129034 & 1.8189 & 1.1445 & 1.1389 & 1.2345 \\
\hline $\mathrm{A}$ & 2.00 & 12 & 2.6012 & 4.11611 & .204595 & 1.6243 & 1.3590 & 2.1543 & 2.4490 \\
\hline A & 3.00 & 12 & 2.98024 & 4.46046 & .37299 & 1.3497 & 1.4736 & 2.3397 & 3.4396 \\
\hline
\end{tabular}




\begin{tabular}{c|c|c|c|c|c|c|c|c|c}
\hline & Pr. & .87 & .0301 & 3.36552 & .083 & 1.833 & .124 & .9722 & .3636 \\
\hline & Total & 36 & 2.45500 & .01268 & .44711 & 1.3457 & 1.223 & 2.30 & 3.20 \\
\hline B & 1.00 & 12 & 1.51072 & 2.02856 & 1.19034 & 1.2989 & 1.2545 & 1.1389 & 1.445 \\
\hline B & 2.00 & 12 & 2.5712. & 3.30611 & .624595 & 1.3343 & 1.4890 & 2.2743 & 2.4190 \\
\hline B & 3.00 & 12 & 2.9215 & 3.10046 & .565299 & 1.6597 & 1.5636 & 2.6597 & 3.0791 \\
\hline & Pr. & .87 & .03009 & .31552 & .5303 & 1.233 & .105 & .9512 & .13226 \\
\hline & Total & 36 & 2.3510 & 4.1268 & .86711 & 1.2157 & 1.2043 & 1.40 & 2.380 \\
\hline C & 1.00 & 12 & 1.42204 & 2.59856 & .179034 & 1.3289 & 1.2345 & 1.2739 & 1.2545 \\
\hline C & 2.00 & 12 & 2.5212. & 3.91611 & .52595 & 1.3443 & 1.4290 & 2.2243 & 2.1190 \\
\hline C & 3.00 & 12 & 3.09124 & 2.62046 & .26299 & 1.1957 & 1.3436 & 2.8507 & 3.2766 \\
\hline & Pr. & .87 & .045201 & .76552 & .003 & .933 & .054 & .9822 & .2136 \\
\hline & Total & 36 & 2.65500 & 4.20268 & .66711 & 1.3057 & 1.2043 & 2.150 & 3.33 \\
\hline
\end{tabular}

\begin{tabular}{c|c|c|c|c|c|c}
\hline \multirow{2}{*}{} & \multicolumn{7}{|c}{ ANOVA } \\
\cline { 2 - 7 } & ATM2 & Sum of squares & df & Mean square & F & Sig. \\
\hline & Between groups & 79.100 & 17 & 44.250 & 1.62 & .005 \\
\hline & Within groups & 603.015 & 35 & 85.513 & & \\
\hline & Total & 682.110 & 52 & & & \\
\hline
\end{tabular}

Post hoc tests

\section{Homogeneous Subsets}

$S P C$

ATM2

Duncan $^{\text {a }}$

\begin{tabular}{|c|c|c|c|c|c|}
\hline \multirow{2}{*}{ ABT } & \multirow{2}{*}{ ATM2 } & \multirow{2}{*}{$\mathbf{N}$} & \multicolumn{3}{|c|}{ Subset for alpha $=0.05$} \\
\hline & & & 1 & 2 & 3 \\
\hline A & 3.00 & 12 & 2.98167 & & \\
\hline A & 2.00 & 12 & & 2.50327 & \\
\hline \multirow[t]{2}{*}{ A } & 1.00 & 12 & & & 1.33067 \\
\hline & Sig. & .025 & & & \\
\hline B & 3.00 & 12 & 2.92017 & & \\
\hline B & 2.00 & 12 & & 2.67027 & \\
\hline \multirow[t]{2}{*}{ B } & 1.00 & 12 & & & 1.33017 \\
\hline & Sig. & .025 & & & \\
\hline $\mathrm{C}$ & 3.00 & 12 & 3.11167 & & \\
\hline $\mathrm{C}$ & 2.00 & 12 & & 2.92027 & \\
\hline \multirow[t]{2}{*}{$\mathrm{C}$} & 1.00 & 12 & & & 1.36721 \\
\hline & Sig. & .025 & & & \\
\hline
\end{tabular}

Means for groups in homogeneous subsets are displayed

${ }^{\mathrm{a} U s e s}$ harmonic mean sample size $=12.000$ 
ANOVA for dependent variable: SPC, spore count and psychrophilic bacterial count on brining levels in different abattoirs

$S P C$

\begin{tabular}{|c|c|c|c|c|c|c|c|c|c|}
\hline \multirow{3}{*}{ ATM } & \multicolumn{9}{|c|}{ Descriptives } \\
\hline & \multirow{2}{*}{ PSC1 } & \multirow{2}{*}{$\mathbf{N}$} & \multirow{2}{*}{ Mean } & \multirow{2}{*}{$\begin{array}{l}\text { Std. } \\
\text { dev. }\end{array}$} & \multirow{2}{*}{$\begin{array}{l}\text { Std. } \\
\text { error }\end{array}$} & \multicolumn{2}{|c|}{$\begin{array}{c}95 \% \text { confidence interval for } \\
\text { mean }\end{array}$} & \multirow{2}{*}{ Min. } & \multirow{2}{*}{ Max. } \\
\hline & & & & & & Lower bound & Upper bound & & \\
\hline A & .00 & 6 & 3.2333 & .75277 & .30732 & .5432 & 1.7661 & 2.0433 & 3.6233 \\
\hline A & 15.00 & 6 & 2.6667 & .75277 & .30732 & .5565 & 1.4331 & 1.3767 & 2.9567 \\
\hline A & 20.00 & 6 & 2.2733 & .81650 & .33333 & .0986 & 1.8932 & 2.1765 & 2.1902 \\
\hline A & 25.00 & 6 & 2.1133 & 1.4719 & .60093 & .7821 & .98821 & 1.8886 & 2.3781 \\
\hline A & 30.00 & 6 & 1.9166 & .51640 & .21082 & .6786 & 1.7699 & 1.9127 & 2.8086 \\
\hline \multirow[t]{3}{*}{ A } & 35.00 & 6 & 1.3336 & .75227 & .30732 & .5698 & 1.9883 & 1.0767 & 1.9567 \\
\hline & $\operatorname{Pr}$ & .87 & .00121 & 1.1912 & 61911 & 1.987 & 1.8990 & .04521 & .1765 \\
\hline & Total & 36 & 2.0166 & 3.7148 & .35321 & 1.007 & 1.7236 & 1.2310 & 3.231 \\
\hline B & .00 & 6 & 3.0013 & .63277 & .32782 & .4332 & 1.6961 & 2.3343 & 3.7633 \\
\hline $\mathrm{B}$ & 15.00 & 6 & 2.3334 & .72277 & .31332 & .6715 & 1.7731 & 14467 & 2.5467 \\
\hline $\mathrm{B}$ & 20.00 & 6 & 2.1902 & .91250 & .41333 & .4216 & 1.5932 & 2.2765 & 2.7702 \\
\hline B & 25.00 & 6 & 2.0913 & 1.5719 & .71093 & .3891 & 1.7821 & 1.6667 & 2.4481 \\
\hline $\mathrm{B}$ & 30.00 & 6 & 1.8916 & .51640 & .43182 & .5092 & 1.6699 & 1.5127 & 2.7686 \\
\hline \multirow[t]{3}{*}{ B } & 35.00 & 6 & 1.6713 & .55177 & .35732 & .5923 & 1.7983 & 1.3767 & 1.5867 \\
\hline & $\operatorname{Pr}$ & .87 & .00111 & 1.1912 & .51914 & .7637 & 1.8954 & .07521 & .1965 \\
\hline & Total & 36 & 2.0166 & 3.3348 & .58371 & 4007 & 1.5636 & 1.4210 & 3.7631 \\
\hline $\mathrm{C}$ & .00 & 6 & 3.1333 & .43237 & .29732 & .4332 & 1.6543 & 2.0433 & 3.9933 \\
\hline $\mathrm{C}$ & 15.00 & 6 & 1.9667 & .76271 & .31402 & .6665 & 1.5441 & 1.5767 & 2.7867 \\
\hline $\mathrm{C}$ & 20.00 & 6 & 2.3333 & .71650 & .41933 & .8986 & 1.9344 & 2.0765 & 2.5502 \\
\hline $\mathrm{C}$ & 25.00 & 6 & 2.1123 & .94719 & 61593 & .8621 & 1.4821 & 1.6986 & 2.6581 \\
\hline $\mathrm{C}$ & 30.00 & 6 & 1.8726 & .41620 & .33482 & .7686 & 1.5455 & 1.4427 & 2.3486 \\
\hline \multirow[t]{3}{*}{$\mathrm{C}$} & 35.00 & 6 & 1.1726 & .65237 & .45732 & .7598 & 1.7881 & 1.6767 & 1.9067 \\
\hline & $\operatorname{Pr}$ & .87 & .00111 & 1.2912 & .44321 & 6987 & 1.7691 & .06521 & .1865 \\
\hline & Total & 36 & 2.0166 & 3.1148 & .4192 & 6707 & 1.8236 & 1.410 & 3.731 \\
\hline
\end{tabular}

\begin{tabular}{|c|c|c|c|c|c|}
\hline \multicolumn{6}{|c|}{ ANOVA } \\
\hline PSC1 & Sum of squares & df & Mean square & $\mathbf{F}$ & Sig. \\
\hline Between groups & 459.000 & 11 & 91.800 & 10.5420 & .000 \\
\hline Within groups & 524.000 & 30 & .800 & & \\
\hline Total & 983.000 & 41 & & & \\
\hline
\end{tabular}

Spores count

\begin{tabular}{l|c|c|c|c|c|c|c|c}
\hline \multicolumn{1}{|c}{ Descriptives } \\
\hline ATM & PSC1 & N & Mean & $\begin{array}{c}\text { Std. } \\
\text { dev. }\end{array}$ & $\begin{array}{c}\text { Std. } \\
\text { error }\end{array}$ & $\begin{array}{c}95 \% \text { confidence interval for } \\
\text { mean }\end{array}$ & Min. & Max. \\
\hline
\end{tabular}




\begin{tabular}{c|c|c|c|c|c|c|c|c|c}
\hline & & & & & & Lower bound & Upper bound & & \\
\hline $\mathrm{A}$ & .00 & 6 & 3.1833 & .75277 & .30732 & .5432 & 1.7661 & 2.0433 & 3.6233 \\
\hline $\mathrm{A}$ & 15.00 & 6 & 2.4737 & .75277 & .30732 & .5565 & 1.4331 & 1.3767 & 2.9567 \\
\hline $\mathrm{A}$ & 20.00 & 6 & 2.2833 & .81650 & .33333 & .0986 & 1.8932 & 2.1765 & 2.1902 \\
\hline $\mathrm{A}$ & 25.00 & 6 & 2.1033 & 1.4719 & .60093 & .7821 & .98821 & 1.8886 & 2.3781 \\
\hline $\mathrm{A}$ & 30.00 & 6 & 1.8916 & .51640 & .21082 & .6786 & 1.7699 & 1.9127 & 2.8086 \\
\hline $\mathrm{A}$ & 35.00 & 6 & 1.2336 & .75227 & .30732 & .5698 & 1.9883 & 1.0767 & 1.9567 \\
\hline & $\operatorname{Pr}$ & .87 & .02121 & 1.1912 & .61911 & 1.987 & 1.8990 & .04521 & .1765 \\
\hline & Total & 36 & 2.6236 & 3.7148 & .55211 & 1.007 & 1.7236 & 1.2310 & 3.231 \\
\hline $\mathrm{B}$ & .00 & 6 & 3.2513 & .63277 & .32782 & .4332 & 1.6961 & 2.3343 & 3.7633 \\
\hline $\mathrm{B}$ & 15.00 & 6 & 2.4334 & .72277 & .31332 & .6715 & 1.7731 & 14467 & 2.5467 \\
\hline $\mathrm{B}$ & 20.00 & 6 & 2.2702 & .91250 & .41333 & .4216 & 1.5932 & 2.2765 & 2.7702 \\
\hline $\mathrm{B}$ & 25.00 & 6 & 2.1113 & 1.5719 & .71093 & .3891 & 1.7821 & 1.6667 & 2.4481 \\
\hline $\mathrm{B}$ & 30.00 & 6 & 1.8816 & .51640 & .43182 & .5092 & 1.6699 & 1.5127 & 2.7686 \\
\hline $\mathrm{B}$ & 35.00 & 6 & 1.5613 & .55177 & .35732 & .5923 & 1.7983 & 1.3767 & 1.5867 \\
\hline & $\operatorname{Pr}$ & .87 & .03521 & 1.1912 & .51914 & .7637 & 1.8954 & .07521 & .1965 \\
\hline & Total & 36 & 2.3166 & 3.3348 & .44441 & .4007 & 1.5636 & 1.4210 & 3.7631 \\
\hline $\mathrm{C}$ & .00 & 6 & 3.3033 & .43237 & .29732 & .4332 & 1.6543 & 2.0433 & 3.9933 \\
\hline $\mathrm{C}$ & 15.00 & 6 & 2.5227 & .76271 & .31402 & .6665 & 1.5441 & 1.5767 & 2.7867 \\
\hline $\mathrm{C}$ & 20.00 & 6 & 2.2533 & .71650 & .41933 & .8986 & 1.9344 & 2.0765 & 2.5502 \\
\hline $\mathrm{C}$ & 25.00 & 6 & 2.0823 & .94719 & .61593 & .8621 & 1.4821 & 1.6986 & 2.6581 \\
\hline $\mathrm{C}$ & 30.00 & 6 & 1.9026 & .41620 & .33482 & .7686 & 1.5455 & 1.4427 & 2.3486 \\
\hline $\mathrm{C}$ & 35.00 & 6 & 1.4726 & .65237 & .45732 & .7598 & 1.7881 & 1.6767 & 1.9067 \\
\hline & $\operatorname{Pr}$ & .87 & .03312 & 1.2912 & .44321 & .6987 & 1.7691 & .06521 & .1865 \\
\hline & Total & 36 & 2.0106 & 3.1148 & .4192 & .6707 & 1.8236 & 1.410 & 3.731 \\
\hline & & & & & & & & &
\end{tabular}

\begin{tabular}{c|c|c|c|c|c}
\hline \multicolumn{7}{|c}{ ANOVA } \\
\hline PSC1 & Sum of squares & df & Mean square & F & Sig. \\
\hline Between groups & 513.139 & 11 & 102.628 & 136.837 & .000 \\
\hline Within groups & 22.500 & 30 & .750 & & \\
\hline Total & 535.639 & 41 & & & \\
\hline
\end{tabular}

Psychrophilic

\begin{tabular}{|c|c|c|c|c|c|c|c|c|c|}
\hline \multicolumn{10}{|c|}{ Descriptives } \\
\hline \multirow{2}{*}{ ATM } & \multirow{2}{*}{ PSC1 } & \multirow[t]{2}{*}{$\mathbf{N}$} & \multirow[t]{2}{*}{ Mean } & \multirow{2}{*}{$\begin{array}{l}\text { Std. } \\
\text { dev. }\end{array}$} & \multirow{2}{*}{$\begin{array}{l}\text { Std. } \\
\text { error }\end{array}$} & \multicolumn{2}{|c|}{$\begin{array}{l}\text { 95\% confidence interval for } \\
\text { mean }\end{array}$} & \multirow[t]{2}{*}{ Min. } & \multirow[t]{2}{*}{ Max. } \\
\hline & & & & & & Lower bound & Upper bound & & \\
\hline A & .00 & 6 & 3.9333 & .75277 & .30732 & .5432 & 1.7661 & 2.0433 & 3.6233 \\
\hline $\mathrm{A}$ & 15.00 & 6 & 3.1667 & .75277 & .30732 & .5565 & 1.4331 & 1.3767 & 2.9567 \\
\hline A & 20.00 & 6 & 2.8733 & .81650 & .33333 & .0986 & 1.8932 & 2.1765 & 2.1902 \\
\hline A & 25.00 & 6 & 2.2133 & 1.4719 & .60093 & .7821 & .98821 & 1.8886 & 2.3781 \\
\hline A & 30.00 & 6 & 1.5216 & .51640 & .21082 & .6786 & 1.7699 & 1.9127 & 2.8086 \\
\hline A & 35.00 & 6 & 1.1336 & .75227 & .30732 & .5698 & 1.9883 & 1.0767 & 1.9567 \\
\hline
\end{tabular}




\begin{tabular}{c|c|c|c|c|c|c|c|c|c}
\hline & Pr & .87 & .04121 & 1.1912 & .61911 & 1.987 & 1.8990 & .04521 & .1765 \\
\hline & Total & 36 & 2.3157 & 3.7148 & .25213 & 1.007 & 1.7236 & 1.2310 & 3.231 \\
\hline B & .00 & 6 & 3.6013 & .63277 & .32782 & .4332 & 1.6961 & 2.3343 & 3.7633 \\
\hline B & 15.00 & 6 & 3.3334 & .72277 & .31332 & .6715 & 1.7731 & 14467 & 2.5467 \\
\hline B & 20.00 & 6 & 2.7902 & .91250 & .41333 & .4216 & 1.5932 & 2.2765 & 2.7702 \\
\hline B & 25.00 & 6 & 2.1413 & 1.5719 & .71093 & .3891 & 1.7821 & 1.6667 & 2.4481 \\
\hline B & 30.00 & 6 & 1.6916 & .51640 & .43182 & .5092 & 1.6699 & 1.5127 & 2.7686 \\
\hline B & 35.00 & 6 & 1.0713 & .55177 & .35732 & .5923 & 1.7983 & 1.3767 & 1.5867 \\
\hline & Pr & .87 & .04411 & 1.1912 & .51914 & .7637 & 1.8954 & .07521 & .1965 \\
\hline & Total & 36 & 2.0166 & 3.3348 & .38371 & .4007 & 1.5636 & 1.4210 & 3.7631 \\
\hline C & .00 & 6 & 4.1333 & .43237 & .29732 & .4332 & 1.6543 & 2.0433 & 3.9933 \\
\hline C & 15.00 & 6 & 2.9667 & .76271 & .31402 & .6665 & 1.5441 & 1.5767 & 2.7867 \\
\hline C & 20.00 & 6 & 2.4333 & .71650 & .41933 & .8986 & 1.9344 & 2.0765 & 2.5502 \\
\hline C & 25.00 & 6 & 2.0213 & .94719 & .61593 & .8621 & 1.4821 & 1.6986 & 2.6581 \\
\hline C & 30.00 & 6 & 1.4726 & .41620 & .33482 & .7686 & 1.5455 & 1.4427 & 2.3486 \\
\hline C & 35.00 & 6 & 1.1126 & .65237 & .45732 & .7598 & 1.7881 & 1.6767 & 1.9067 \\
\hline & Pr & .87 & .02611 & 1.2912 & .44321 & .6987 & 1.7691 & .06521 & .1865 \\
\hline & Total & 36 & 2.0166 & 3.1148 & .2192 & .6707 & 1.8236 & 1.410 & 3.731 \\
\hline
\end{tabular}

\begin{tabular}{c|c|c|c|c|c}
\hline \multicolumn{7}{c}{ ANOVA } & F & Sig. \\
\hline PSC1 & Sum of squares & df & Mean & 1.146 & .003 \\
\hline Between groups & 28.389 & 11 & 14.194 & & \\
\hline Within groups & 408.583 & 33 & 12.381 & & \\
\hline Total & 436.972 & 41 & & & \\
\hline
\end{tabular}

Post hoc tests

Homogeneous subsets

$S P C$

BRINE1

Duncan $^{\text {a }}$

\begin{tabular}{c|c|c|c|c|c|c}
\hline \multirow{2}{*}{ ATM } & \multirow{2}{*}{ BRINE1 } & \multirow{2}{*}{$\mathbf{N}$} & \multicolumn{4}{|c}{ Subset for alpha $=\mathbf{0 . 0 5}$} \\
\cline { 4 - 7 } & & & $\mathbf{1}$ & $\mathbf{2}$ & $\mathbf{3}$ & $\mathbf{4}$ \\
\hline $\mathrm{A}$ & 35.00 & 6 & 1.33333 & & & \\
\hline $\mathrm{A}$ & 30.00 & 6 & 1.92167 & & & \\
\hline $\mathrm{A}$ & 25.00 & 6 & & 2.11333 & & \\
\hline $\mathrm{A}$ & 20.00 & 6 & & & 2.27333 & \\
\hline $\mathrm{A}$ & 15.00 & 6 & & & 2.67333 & \\
\hline $\mathrm{A}$ & .00 & 6 & & & & 3.23167 \\
\hline & Sig. & & .341 & .341 & .117 & .112 \\
\hline B & 35.00 & 6 & 1.67333 & & & \\
\hline B & 30.00 & 6 & 1.89167 & & & \\
\hline B & 25.00 & 6 & & 2.09333 & & \\
\hline B & 20.00 & 6 & & 2.19333 & & \\
\hline
\end{tabular}




\begin{tabular}{c|c|c|c|c|c|c}
\hline B & 15.00 & 6 & & & 2.3316 & \\
\hline B & .00 & 6 & & & & 3.0017 \\
\hline & Sig. & & .341 & .341 & .117 & .112 \\
\hline C & 35.00 & 6 & 1.17333 & & & \\
\hline C & 30.00 & 6 & 1.87167 & & & \\
\hline C & 25.00 & 6 & & 2.12333 & & \\
\hline C & 20.00 & 6 & & 2.33333 & & \\
\hline C & 15.00 & 6 & & & 1.97333 & \\
\hline C & .00 & 6 & & & & 3.13167 \\
\hline & Sig. & & .341 & .341 & .117 & .112 \\
\hline
\end{tabular}

Means for groups in homogeneous subsets are displayed

${ }^{a}$ Uses harmonic mean sample size $=6.000$

ANOVA for dependent variable: SPC, spore count and psychrotrophic bacterial load for antimicrobial intervention and brining

Antimicrobials intervention

\begin{tabular}{|c|c|c|c|c|c|c|c|c|c|}
\hline \multicolumn{10}{|c|}{ Descriptives } \\
\hline \multirow[t]{2}{*}{ ABT } & \multirow[t]{2}{*}{ ATM2 } & \multirow[t]{2}{*}{$\mathbf{N}$} & \multirow[t]{2}{*}{ Mean } & \multirow[t]{2}{*}{ Std. dev. } & \multirow[t]{2}{*}{ Std. error } & \multicolumn{2}{|c|}{$\begin{array}{l}95 \% \text { confidence interval for } \\
\text { mean }\end{array}$} & \multirow[t]{2}{*}{ Min. } & \multirow[t]{2}{*}{ Max. } \\
\hline & & & & & & Lower bound & Upper bound & & \\
\hline SPC & 1.00 & 12 & 1.1733 & .93361 & .84686 & 1.4694 & 2.1973 & .063 & 1.00 \\
\hline SPC & 2.00 & 12 & 2.4720 & .77793 & 1.09059 & 2.0996 & 2.9004 & 1.50 & 2.50 \\
\hline \multirow[t]{3}{*}{$\mathrm{SPC}$} & 3.00 & 12 & 2.3048 & .77692 & 1.09030 & 1.1836 & 2.9831 & 2.50 & 2.50 \\
\hline & Pr. & .87 & .023 & .33729 & .26711 & .4457 & .6674 & .987 & .0887 \\
\hline & Total & 36 & 1.772 & 1.53340 & .58890 & 4.2767 & 14.6678 & 7.00 & 21.00 \\
\hline Spores & 1.00 & 12 & 1.4733 & .45361 & .23446 & 1.3294 & 2.9273 & 1.00 & 3.00 \\
\hline Spores & 2.00 & 12 & 3.0107 & .87293 & 1.5932 & 2.1236 & 3.1004 & .605 & 2.70 \\
\hline \multirow[t]{3}{*}{ Spores } & 3.00 & 12 & 3.4203 & .76692 & 1.0370 & 1.2656 & 2.8651 & 1.09 & 3.50 \\
\hline & Pr. & .87 & .044 & 1.8762 & .4121 & .6652 & .8875 & .876 & .987 \\
\hline & Total & 36 & 2.2072 & 1.61120 & .36790 & 3.4267 & 7.6678 & 2.340 & 8.201 \\
\hline PSY & 1.00 & 12 & 1.3933 & .77461 & .67186 & 1.3344 & 3.1373 & .090 & 3.00 \\
\hline PSY & 2.00 & 12 & 2.3040 & .59193 & .99059 & 1.4316 & 2.8704 & 1.00 & 1.52 \\
\hline \multirow[t]{3}{*}{ PSY } & 3.00 & 12 & 3.0831 & .68222 & .43030 & 1.2836 & 1.6831 & 2.50 & 1.30 \\
\hline & Pr. & .87 & .001 & 1.2331 & .3211 & .9982 & .5542 & .4333 & .3244 \\
\hline & Total & 36 & 2.0612 & 1.3140 & 1.0090 & 3.5437 & 6.3378 & 4.030 & 5.00 \\
\hline
\end{tabular}

\begin{tabular}{l|c|c|c|c|c|c}
\hline \multicolumn{7}{c}{ ANOVA } \\
\hline & ATM2 & Sum of s & df & Mean & F & Sig. \\
\hline & Between groups & 28.389 & 8 & 14.194 & 1.146 & .003 \\
\hline & Within groups & 408.583 & 26 & 12.381 & & \\
\hline & Total & 436.972 & 34 & & & \\
\hline
\end{tabular}


Post hoc tests

Homogeneous subsets

ATM2

Duncan $^{\mathrm{a}}$

\begin{tabular}{|c|c|c|c|c|c|}
\hline \multirow{2}{*}{ Microbe } & \multirow{2}{*}{ ATM2 } & \multirow{2}{*}{$\mathbf{N}$} & \multicolumn{3}{|c|}{ Subset for alpha $=0.05$} \\
\hline & & & 1 & 2 & 3 \\
\hline & 3.00 & 12 & 3.21 & & \\
\hline \multirow[t]{5}{*}{ SPC } & 2.00 & 12 & & 2.25 & \\
\hline & 1.00 & 12 & & & 1.17333 \\
\hline & Sig. & & .003 & & \\
\hline & 3.00 & 12 & 3.42 & & \\
\hline & 2.00 & 12 & & 3.01 & \\
\hline \multirow[t]{4}{*}{ Spores } & 1.00 & 12 & & & 1.47 \\
\hline & Sig. & & .003 & & \\
\hline & 3.00 & 12 & 3.08 & & \\
\hline & 2.00 & 12 & & 2.30 & \\
\hline \multirow[t]{2}{*}{ PSY } & 1.00 & 12 & & & 1.39 \\
\hline & Sig. & & .003 & & \\
\hline
\end{tabular}

Means for groups in homogeneous subsets are displayed

${ }^{a}$ Uses harmonic mean sample size $=12.000$

BRINING

\begin{tabular}{|c|c|c|c|c|c|c|c|c|c|}
\hline \multicolumn{10}{|c|}{ Descriptives } \\
\hline ABT & \multirow{2}{*}{ Brine } & \multirow[t]{2}{*}{$\mathbf{N}$} & \multirow{2}{*}{ Mean } & \multirow[t]{2}{*}{ Std. dev. } & \multirow{2}{*}{$\begin{array}{l}\text { Std. } \\
\text { error }\end{array}$} & \multicolumn{2}{|c|}{$\begin{array}{l}95 \% \text { confidence interval for } \\
\text { mean }\end{array}$} & \multirow[t]{2}{*}{ Min. } & \multirow[t]{2}{*}{ Max. } \\
\hline Microbes & & & & & & Lower bound & Upper bound & & \\
\hline SPC & .00 & 6 & 3.33333 & .93361 & .84686 & 1.4694 & 2.1973 & .063 & 1.00 \\
\hline SPC & 15.00 & 6 & 2.87267 & .77793 & 1.09059 & 2.0996 & 2.9004 & 1.50 & 2.50 \\
\hline SPC & 20.00 & 6 & 2.63167 & .77692 & 1.09030 & 1.1836 & 2.9831 & 2.50 & 2.50 \\
\hline SPC & 25.00 & 6 & 2.32223 & .66792 & .44592 & 2.0882 & 2.6551 & 0.87 & 3.12 \\
\hline SPC & 30.00 & 6 & 1.76333 & 1.2331 & .67552 & 1.7763 & 2.0898 & 1.45 & 3.08 \\
\hline \multirow[t]{3}{*}{$\mathrm{SPC}$} & 35.00 & 6 & 1.57333 & .98872 & .43552 & 0.8778 & 1.6652 & 2.45 & 2.99 \\
\hline & Pr. & .87 & .02311 & .33729 & .26711 & .4457 & .6674 & .987 & .0887 \\
\hline & Total & 36 & 11.1944 & 1.53340 & .58890 & 4.2767 & 14.6678 & 7.00 & 21.00 \\
\hline Spore & .00 & 6 & 3.25012 & .45361 & .23446 & 1.3294 & 2.9273 & 1.00 & 3.00 \\
\hline Spore & 15.00 & 6 & 2.43771 & .87293 & 1.5932 & 2.1236 & 3.1004 & .605 & 2.70 \\
\hline Spore & 20.00 & 6 & 2.12111 & .76692 & 1.0370 & 1.2656 & 2.8651 & 1.09 & 3.50 \\
\hline Spore & 25.00 & 6 & 2.11066 & .93361 & .84686 & 1.4694 & 2.1973 & .063 & 1.00 \\
\hline Spore & 30.00 & 6 & 1.87122 & .77793 & \begin{tabular}{|l|}
1.09059 \\
\end{tabular} & 2.0996 & 2.9004 & 1.50 & 2.50 \\
\hline \multirow[t]{3}{*}{ Spore } & 35.00 & 6 & 1.56233 & .77692 & \begin{tabular}{|l|}
1.09030 \\
\end{tabular} & 1.1836 & 2.9831 & 2.50 & 2.50 \\
\hline & Pr. & .87 & 0.044 & 1.2331 & .3211 & .9982 & .5542 & .4333 & .3244 \\
\hline & Total & 36 & 11.6772 & 1.3140 & 1.0090 & 3.5437 & 6.3378 & 4.030 & 5.00 \\
\hline PSC & .00 & 6 & 3.63122 & .77461 & .67186 & 1.3344 & 3.1373 & .090 & 3.00 \\
\hline PSC & 15.00 & 6 & 3.32122 & .59193 & .99059 & 1.4316 & 2.8704 & 1.00 & 1.52 \\
\hline
\end{tabular}




\begin{tabular}{c|c|c|c|c|c|c|c|c|c}
\hline PSC & 20.00 & 6 & 2.79341 & .68222 & .43030 & 1.2836 & 1.6831 & 2.50 & 1.30 \\
\hline PSC & 25.00 & 6 & 2.13021 & .45361 & .23446 & 1.3294 & 2.9273 & 1.00 & 3.00 \\
\hline PSC & 30.00 & 6 & 1.69872 & .87293 & 1.5932 & 2.1236 & 3.1004 & .605 & 2.70 \\
\hline PSC & 35.00 & 6 & 1.05782 & .76692 & 1.0370 & 1.2656 & 2.8651 & 1.09 & 3.50 \\
\hline & Pr. & .87 & 0.001 & 1.8762 & .4121 & .6652 & .8875 & .876 & .987 \\
\hline & Total & 36 & 12.7662 & 1.61120 & .36790 & 3.4267 & 7.6678 & 2.340 & 8.201 \\
\hline
\end{tabular}

\section{ANOVA}

\section{BRINE}

\begin{tabular}{c|c|c|c|c|c}
\hline & Sum of s & df & Mean & F & Sig. \\
\hline Between groups & 28.389 & 8 & 14.194 & 1.146 & .003 \\
\hline Within groups & 408.583 & 26 & 12.381 & & \\
\hline Total & 436.972 & 34 & & & \\
\hline
\end{tabular}

\section{Post hoc tests}

Homogeneous subsets

\begin{tabular}{c|c|c|c|c|c|c}
\hline \multicolumn{7}{c}{ DRINE1 $^{\circ}$} \\
\hline \multirow{2}{*}{ Microbes } & \multirow{2}{*}{ BRINE } & \multirow{2}{*}{ N } & \multicolumn{3}{c}{ Subset for alpha $=\mathbf{0 . 0 5}$} \\
\cline { 4 - 7 } & & & $\mathbf{1}$ & $\mathbf{2}$ & $\mathbf{3}$ & $\mathbf{4}$ \\
\hline SPC & 35.00 & 6 & 1.57333 & & & \\
\hline SPC & 30.00 & 6 & 1.76333 & & & \\
\hline SPC & 25.00 & 6 & & 2.32333 & & \\
\hline SPC & 20.00 & 6 & & & 2.6311 & \\
\hline SPC & 15.00 & 6 & & & 2.8711 & \\
\hline SPC & .00 & 6 & & & & 3.3333 \\
\hline & Sig. & & .325 & .106 & .325 & 1.000 \\
\hline Spores & 35.00 & 6 & 1.56112 & & & \\
\hline Spores & 30.00 & 6 & 1.87122 & & & \\
\hline Spores & 25.00 & 6 & & 2.11322 & & \\
\hline Spores & 20.00 & 6 & & 2.11876 & & \\
\hline Spores & 15.00 & 6 & & & 2.42981 & \\
\hline Spores & .00 & 6 & & & & 3.6321 \\
\hline & Sig. & & .145 & .056 & .325 & 1.000 \\
\hline PSC & 35.00 & 6 & 1.06211 & & & \\
\hline PSC & 30.00 & 6 & 1.70212 & & & \\
\hline PSC & 25.00 & 6 & & 2.13321 & & \\
\hline PSC & 20.00 & 6 & & 2.40121 & & \\
\hline PSC & 15.00 & 6 & & & 3.32112 & \\
\hline PSC & .00 & 6 & & & & 3.63112 \\
\hline & Sig. & & .325 & .106 & .325 & 1.000 \\
\hline
\end{tabular}

Means for groups in homogeneous subsets are displayed aUses harmonic mean sample size $=6.000$ 


\section{Optimization outputs}

Curve fit

Quadratic for SPC

\begin{tabular}{c|c|c|c}
\hline \multicolumn{4}{c}{ Model summary } \\
\hline $\mathbf{R}$ & $\mathbf{R}$ & Adjusted R & Std. error of the estimate \\
\hline .968 & .938 & .896 & 3.999 \\
\hline
\end{tabular}

The independent variable is psychrophiles

\begin{tabular}{c|c|c|c|c|c}
\hline \multicolumn{7}{c}{ ANOVA } & F & Sig. \\
\hline & Sum of s & df & Mean & 22.606 & .016 \\
\hline Regression & 722.869 & 2 & 361.434 & & \\
\hline Residual & 47.964 & 3 & 15.988 & & \\
\hline Total & 770.833 & 5 & & & \\
\hline
\end{tabular}

The independent variable is psychrophiles

\begin{tabular}{|c|c|c|c|c|c|}
\hline \multicolumn{6}{|c|}{ Coefficients } \\
\hline & \multicolumn{2}{|c|}{ Unstandardized coefficients } & $\begin{array}{c}\text { Standardized } \\
\text { coefficients }\end{array}$ & \multirow[t]{2}{*}{$\mathbf{t}$} & \multirow[t]{2}{*}{ Sig. } \\
\hline & B & Std. Error & Beta & & \\
\hline Psychrophiles & 5.909 & 12.090 & .470 & .489 & 659 \\
\hline Psychrophiles $* * 2$ & -3.748 & 2.518 & -1.430 & -1.488 & .233 \\
\hline (Constant) & 31.774 & 13.013 & & 2.442 & .092 \\
\hline
\end{tabular}
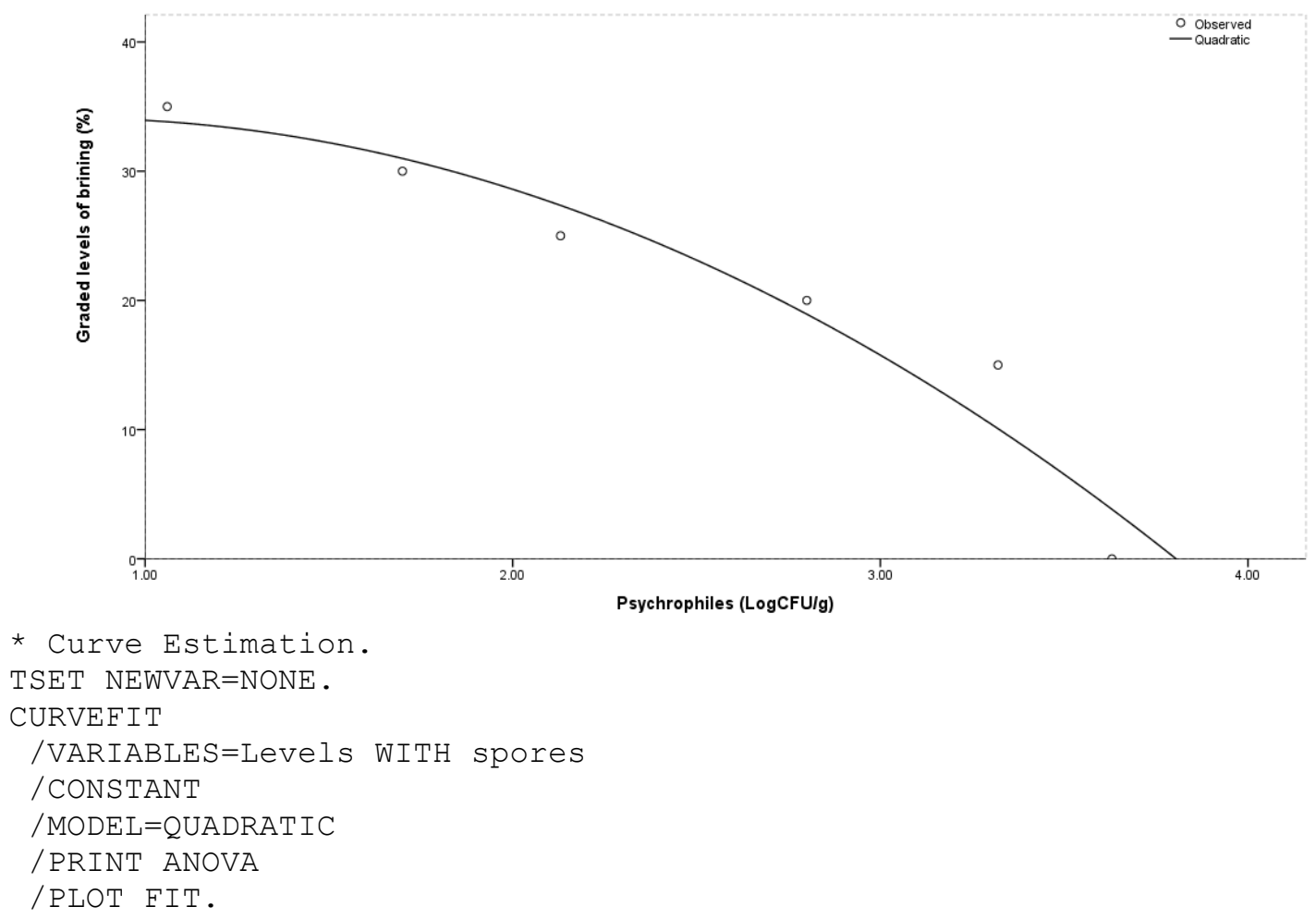
Curve fit

Quadratic for spores

\begin{tabular}{c|c|c|c}
\hline \multicolumn{4}{c}{ Model Summary } \\
\hline $\mathrm{R}$ & $\mathrm{R}$ & Adjusted R & Std. Error of the Estimate \\
\hline .990 & .980 & .966 & 2.281 \\
\hline
\end{tabular}

The independent variable is spores

\begin{tabular}{c|c|c|c|c|c}
\hline \multicolumn{7}{c}{ ANOVA } & F & Sig. \\
\hline & Sum of s & df & Mean & 72.560 & .003 \\
\hline Regression & 755.221 & 2 & 377.611 & & \\
\hline Residual & 15.612 & 3 & 5.204 & & \\
\hline Total & 770.833 & 5 & & & \\
\hline
\end{tabular}

The independent variable is spores

\begin{tabular}{|c|c|c|c|c|c|}
\hline \multicolumn{6}{|c|}{ Coefficients } \\
\hline & \multicolumn{2}{|c|}{ Unstandardized coefficients } & \multirow{2}{*}{$\begin{array}{c}\begin{array}{c}\text { Standardized } \\
\text { coefficients }\end{array} \\
\text { Beta } \\
\end{array}$} & \multirow[t]{2}{*}{$\mathbf{t}$} & \multirow[t]{2}{*}{ Sig. } \\
\hline & B & Std. error & & & \\
\hline spores & -31.793 & 15.683 & -1.487 & -2.027 & .136 \\
\hline spores $* * 2$ & 2.178 & 3.185 & .501 & .684 & .543 \\
\hline (Constant) & 80.142 & 18.453 & & 4.343 & .023 \\
\hline
\end{tabular}

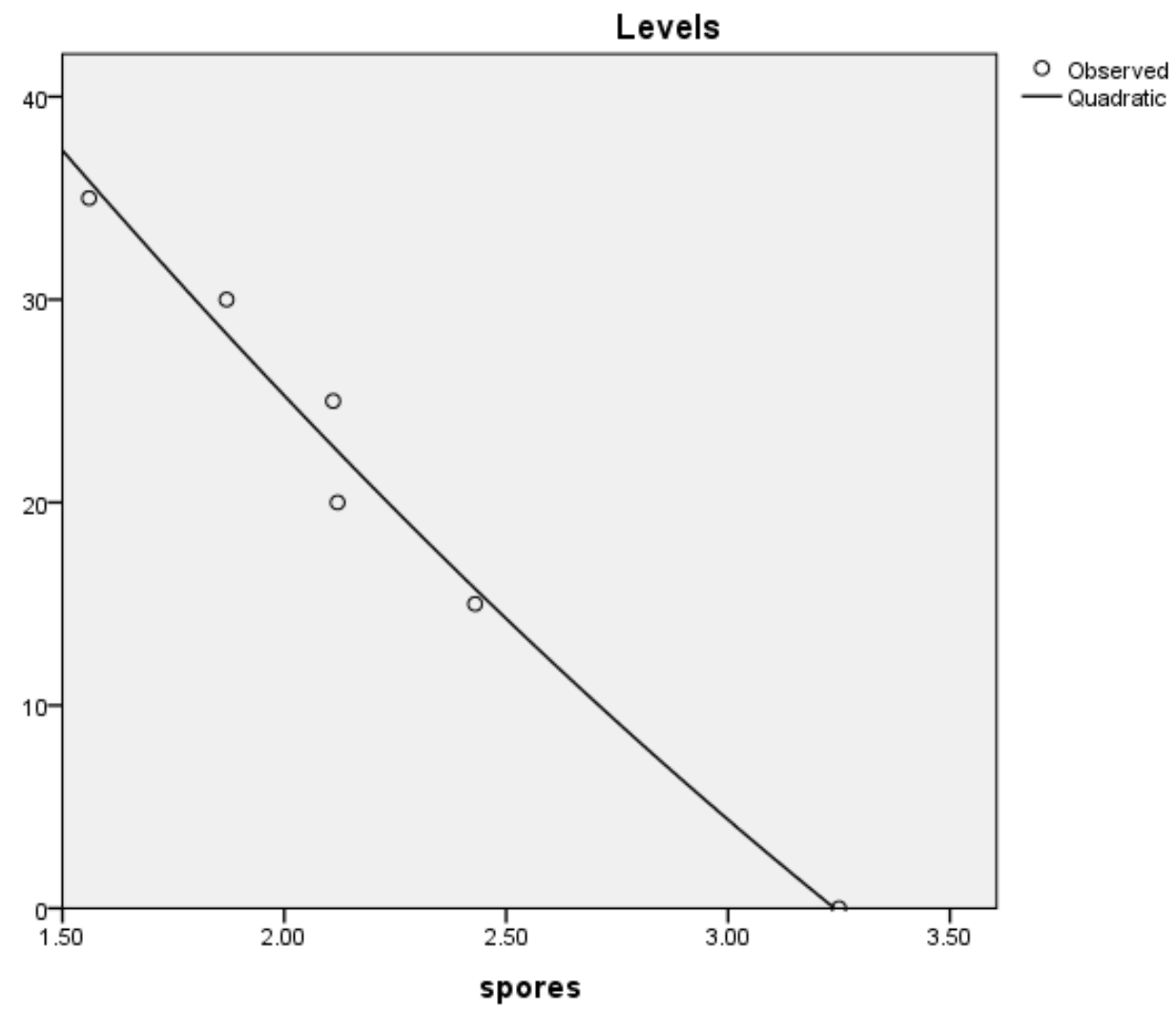


* Curve Estimation.

TSET NEWVAR=NONE .

CURVEFIT

/VARIABLES=Levels WITH SPC

/ CONSTANT

/MODEL=QUADRATIC

/PRINT ANOVA

/PLOT FIT.

\section{Curve fit}

Quadratic for psychrophilic

\begin{tabular}{c|c|c|c}
\hline \multicolumn{4}{c}{ Model summary } \\
\hline $\mathbf{R}$ & $\mathbf{R}$ & Adjusted R & Std. error of the estimate \\
\hline .994 & .988 & .980 & 1.773 \\
\hline
\end{tabular}

The independent variable is SPC

\begin{tabular}{c|c|c|c|c|c}
\hline \multicolumn{7}{c}{ ANOVA } & F & Sig. \\
\hline & Sum of $\mathbf{~}$ & df & Mean & 121.082 & .001 \\
\hline Regression & 761.401 & 2 & 380.700 & & \\
\hline Residual & 9.432 & 3 & 3.144 & & \\
\hline Total & 770.833 & 5 & & & \\
\hline
\end{tabular}

The independent variable is SPC

\begin{tabular}{|c|c|c|c|c|c|}
\hline \multicolumn{6}{|c|}{ Coefficients } \\
\hline & \multicolumn{2}{|c|}{ Unstandardized coefficients } & \multirow{2}{*}{$\begin{array}{c}\begin{array}{c}\text { Standardized } \\
\text { coefficients }\end{array} \\
\text { Beta } \\
\end{array}$} & \multirow[t]{2}{*}{$\mathbf{t}$} & \multirow[t]{2}{*}{ Sig. } \\
\hline & B & Std. Error & & & \\
\hline SPC & 20.578 & 11.093 & 1.110 & 1.855 & .161 \\
\hline $\mathrm{SPC} * * 2$ & -7.986 & 2.286 & -2.090 & -3.494 & .040 \\
\hline (Constant) & 20.670 & 12.794 & & 1.616 & .205 \\
\hline
\end{tabular}

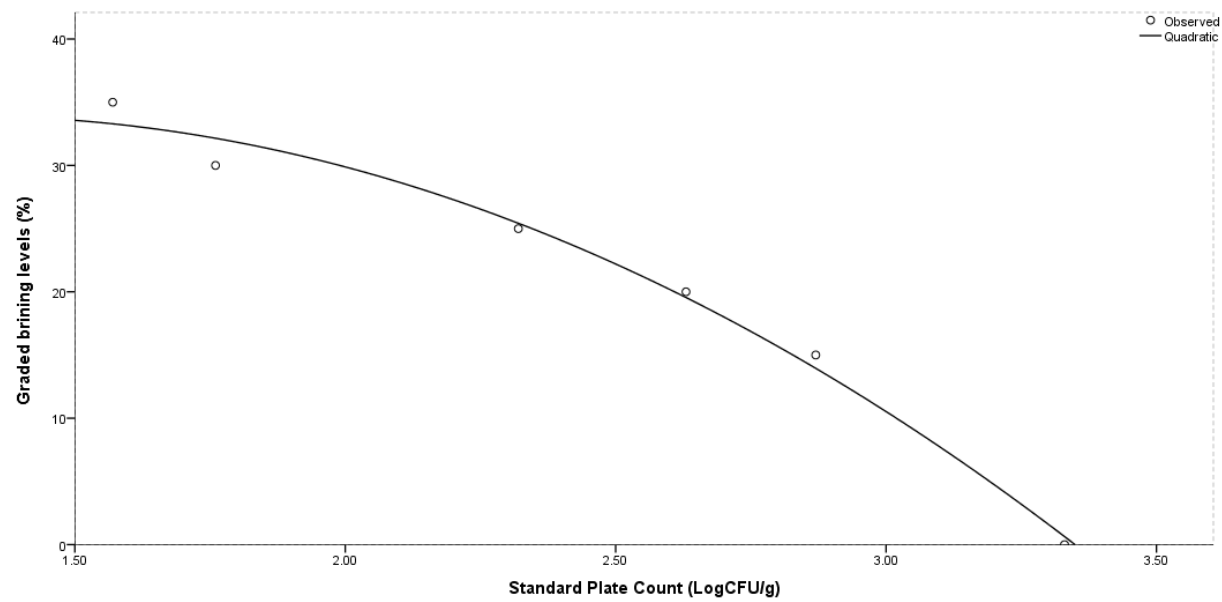

